\title{
The Supply of Corporate Directors and Board Independence*
}

\author{
by \\ Anzhela Knyazeva ${ }^{1}$, Diana Knyazeva ${ }^{2}$, and Ronald Masulis ${ }^{3}$
}

This version: December 13, 2012

\begin{abstract}
Empirical evidence on the relations between board independence and key board decisions, CEO incentives and firm performance is generally confounded by major endogeneity issues. We circumvent these endogeneity problems by demonstrating the strong impact of the local director labor market on corporate board structure for all but the largest quartile of S\&P 1500 firms. Specifically, we show that proximity to larger pools of local director talent leads to significantly more independent boards. Using local director pools as an instrument for board independence in small and medium-sized firms, we reexamine the effects of board independence on firm value, operating performance and CEO incentives. Empirically, we document that board independence has a significant positive impact on firm value and operating performance, and increases CEO pay and turnover sensitivity to performance.
\end{abstract}

JEL: G30, G34

Keywords: board of directors, board expertise, director labor market, location, firm value, firm performance, CEO compensation

\footnotetext{
* We thank Bernard Black, Christa Bouwman, Qianqian Du, Kose John, Jason Kotter, Rafael LaPorta, John Long, Vikram Nanda, Subrata Sarkar, George Serafeim, Cliff Smith, Jerry Warner, Toni Whited, Wanli Zhao, and conference and seminar participants at the 2009 European Financial Management Symposium on Corporate Governance and Control, 2009 Financial Management Association Annual Meetings, 2010 Asian Financial Management Association Meetings, 2010 Australasian Finance and Banking Conference, 2011 SFS Cavalcade, University of Michigan, 2011 Frontiers of Finance Conference at ISB Hyderabad, 2012 American Finance Association Annual Meetings, Dartmouth College, and University of Queensland for valuable comments. The authors gratefully acknowledge the financial support of the William E. Simon Graduate School of Business Administration and the Financial Markets Research Center at Vanderbilt University.

${ }^{1}$ William E. Simon Graduate School of Business Administration, University of Rochester, Rochester, NY 14627, USA, phone: 585-275-3102, email: anzhela.knyazeva@simon.rochester.edu.

${ }^{2}$ William E. Simon Graduate School of Business Administration, University of Rochester, Rochester, NY 14627, USA, phone: 585-275-3211, email: diana.knyazeva@simon.rochester.edu.

${ }^{3}$ Corresponding author. Australian School of Business, University of New South Wales, Sydney, NSW 2052, Australia, phone: +6129385 5860, fax: +61293856347, e-mail: ron.masulis@unsw.edu.au.
} 


\section{Introduction}

Prior research has emphasized the role of the board of directors in monitoring and advising the CEO and the importance of board composition (e.g., Adams and Ferreira, 2007; Fama and Jensen, 1983; Weisbach, 1988 etc.). However, in spite of extensive work on the subject of board independence and shareholder value (see, e.g., Coles, Daniel and Naveen (2008) for a survey of prior literature), the empirical evidence on the effects of board independence on major board decisions and firm performance is often contradictory or lacking in significance. This mixed evidence is in large part attributed to endogeneity issues that arise in the choice of corporate governance mechanisms.

Reinforcing the concern about endogeneity, a growing body of research has focused on the optimal design of corporate boards and firm characteristics associated with the demand for independent director representation on boards (Boone et al., 2007; Raheja, 2005, etc.). Other research has highlighted the role of private benefits of control and CEO influence over director appointments in explaining the level of board independence (e.g., Hermalin and Weisbach, 1998a, 2003, Shivdasani and Yermack, 1999).

We circumvent these endogeneity concerns by exploring the role of the local labor market in supplying directors to firms. Specifically, we show that the ability of most firms to recruit qualified independent directors is significantly affected by the local supply of prospective directors, holding demand side characteristics constant. We use this finding to perform a twostage analysis of the effects of board independence on bottom-line firm outcomes and provide new evidence on the impact of board independence for shareholder wealth and firm performance that is robust to endogeneity. 
We argue that the local availability of qualified prospective directors has an important bearing on a firm's board appointment process. Prospective directors with full-time jobs - many of them executives at other firms - have substantial demands on their time. In short, qualified directors are a scarce human resource, and locating a willing candidate can be time consuming. An average senior executive holds less than one outside board seat, suggesting a reluctance by executives to become overcommitted with outside board responsibilities (Perry and Peyer, 2005; Ferris et al. 2003). Replacing a director following an unexpected departure takes a considerable amount of effort and time (on average 185 days, according to Nguyen and Nielsen (2010)). Since most outside directors come from executive backgrounds (Guner et al., 2008; Linck et al., 2008b), we focus on the pool of current executive officers at nearby firms as the primary source of prospective local directors. Further, as qualified prospective directors have opportunity costs of joining a company's board, they are more likely to accept an appointment at larger firms that offer more visibility and greater director reputation benefits, even if they are more distant. Firms with less visibility are expected to face greater challenges in attracting non-local directors, forcing them to rely more heavily on the local labor market for directors. ${ }^{1}$

Service on a board of a local firm imposes lower costs on an executive: beyond lower transportation costs, there is less time and energy required to travel to board meetings and oversee firm developments outside of formal board meetings. In addition, firms have better access to soft information about the availability of prospective local directors. Overall, we expect firms to face fewer hurdles and be in a better position to attract local candidates to their boards. ${ }^{2}$

\footnotetext{
${ }^{1}$ We also assess whether local labor market constraints are less binding for firms that are more accessible due to their proximity to a major airport. The presumption is that prospective directors will be expected to bear lower travel costs and thus will be willing to travel further to join a firm's board. As a consequence, these firms could be less constrained by local labor markets.

${ }^{2}$ The argument is consistent with the finding in Fahlenbrach, Low and Stulz (2010) and Bouwman (2011) that CEOs are more likely to hold outside directorships at nearby firms. Although we also argue that geographic proximity can facilitate director appointments, unlike those studies, we identify firms that rely more on local prospective directors for independent board
} 
Empirically, we find that the local supply of director candidates available to a firm has important effects on board structure and independent director representation, even after controlling for determinants of board design uncovered in earlier research. Firms close to larger pools of prospective directors have a higher percentage of locally employed independent directors and greater independent director representation on their boards. As expected, smaller and medium-sized firms are more constrained by the local director supply. Further, firm proximity to local pools of valuable expertise in the legal, financial and technological fields is associated with greater board representation of such directors.

We also examine the effect of Sarbanes-Oxley and the associated changes in exchange listing requirements, which serve as an exogenous shock to board composition, on the relation between board independence and local director markets. On the one hand, firms required to add independent directors may draw more heavily on the local pool of prospective directors. On the other hand, firms with thin local labor markets may be forced to pursue a nationwide search to comply with the new law. We find that the relation between local director pools and board independence continues to hold after the imposition of these new regulatory constraints on board composition and specifically on board independence.

Exploiting our finding that local labor markets significantly affect board independence and taking into account the selection of headquarters location predominantly early in a firm's life, we use the variation in the local supply of prospective directors to predict the level of board independence in a two-stage setting. The resulting experimental design enables us to reexamine how board composition affects key firm decisions and outcomes, such as firm value,

appointments and utilize the documented relation between board independence and the local director pool as a source of outside variation in board structure that allows us to reexamine the effects of board structure on a firm's bottom line. Additionally, our analysis allows for a broader range of executive experts within the potential local director pool. 
performance, managerial compensation incentives and CEO turnover. We focus on small and medium-sized companies, which comprise the lower three quartiles of the S\&P 1500, for which local labor market conditions serve as a constraint on the ability to attract independent directors.

Supporting the theoretical predictions concerning the valuable monitoring role of an independent board, we find board independence positively affects firm profitability and operating performance. Consistent with this evidence, markets recognize the benefit of independent boards in the form of higher market valuations. We also find that more independent boards have a higher proportion of CEO incentive based pay to total pay, and all else equal, greater CEO turnover-performance sensitivity. However, total CEO pay is not affected by board independence. ${ }^{3}$ Intuitively, independent boards contribute to improved profitability and higher valuation in part through a better alignment of manager incentives with shareholder interests. We find the effects of board independence change signs, magnitudes and significance levels when we replace ordinary least squares with two-stage least squares estimates. Endogeneity appears to confound the relationship of board independence with performance and value resulting in insignificant effects. Further supporting the importance of correcting for endogeneity, the Hausman test of the differences in ordinary least squares and two-stage least squares coefficients confirms the endogeneity of board independence.

Our findings contribute to the growing literature on corporate boards (see, e.g., Rosenstein and Wyatt, 1990; Yermack, 1996; Yermack, 2004; Guner et al., 2008; Fich, 2005; Linck et al., 2008a; Boone et al., 2007; Masulis and Mobbs, 2011; Brickley et al., 1994). Our study also relates to a handful of board studies that attempt to tackle endogeneity using a variety of approaches. Guo and Masulis (2012), Chhaochharia and Grinstein (2007), and Duchin,

\footnotetext{
${ }^{3}$ This is inconsistent with larger local pools of executives leading to less compensation due to greater competition.
} 
Matsusaka and Ozbas (2010) focus on changes in board independence and composition around the enactment of SOX and the related changes in exchange listing requirements. Nguyen and Nielsen (2010) examine sudden director deaths. Coles et al. (2008) implement a two-stage approach, using firm level characteristics, rather than geographic characteristics as instruments.

Our paper also relates to studies of geographic factors in other financial settings related to the effects of geographic distance on information collection and monitoring by investors (Loughran and Schulz, 2005, 2006; Coval and Moskowitz, 1999, 2001; Brennan and Cao, 1997; Kang and Stulz, 1997 ; Ivkovic and Weisbenner, 2005), by analysts (Malloy, 2005; Bae et al., 2008), VCs (Lerner, 1995; Bengtsson and Ravid, 2011) and on corporate finance decisions such as shareholder payouts (John et al., 2011; Becker et al., 2011), employee relations (Landier et al., 2009) and acquisitions (Kedia et al., 2008; Kang and Kim, 2008). Focusing on the effects of director distance, Bouwman (2011) finds that individuals are more likely to be appointed to boards if they previously held a seat in the same locality or at a firm with a common director. John and Kadyrzhanova (2009) find that firms are less likely to adopt takeover defenses in localities where firms on average exhibit good governance, which is more beneficial for corporate performance if local peer firms also have strong governance practices. Masulis et al. (2011) find that foreign independent directors are less likely to attend board meetings; and firms with foreign directors are more apt to offer higher excess CEO compensation, restate earnings and exhibit significantly poorer performance. Wan (2008) shows that local independent directors are better informed, but less effective monitors, possibly due to greater social dependence, while Alam et al. (2011) report that local independent directors reduce CEO pay, but weaken turnover performance sensitivity. (In contrast, we do not find a separate effect of local directors after controlling for the representation of independent directors.) 
Distinct from this prior literature, we document the effects of the local supply of potential directors on board composition of all but the largest firms and use this variable as an instrument to address endogeneity concerns in the relation between independent boards and firm value. Other recent studies examine changes in board composition after SOX, and analyze time-series variation affecting all firms at once or to obtain more cross sectional variation, condition the effects of the compliance shock on additional firm-level variables, such as pre-SOX board composition or information asymmetry proxies, both of which may be endogenous. In contrast, we are able to incorporate significantly more exogenous variation in board independence across a large sample of firms, adding to the power of our tests.

\section{Data}

Sample

The sample includes Compustat / CRSP firms with available RiskMetrics data on board characteristics and takeover provisions, $13 \mathrm{f}$ data on institutional holdings, and Execucomp data on CEO characteristics and share ownership. We exclude financial firms (6000-6999), regulated utilities (4900-4999), small firms (assets under \$20 million), foreign firms, and firms headquartered outside the continental US. The sample period is 1996-2006. Where director titles are required to identify executive experts, the sample starts in 1998 due to data availability in RiskMetrics. Director titles are taken from BoardEx for the 2002-2008 period for robustness.

\section{Board characteristics}

Following prior work, the main measure of board composition is board independence, defined as the proportion of the board represented by independent (non-gray outside) directors. By contrast, gray directors are outside board members with familial or business ties to the firm or its senior management, which create conflicts of interests that can compromise a board's major 
functions. ${ }^{4}$ Robustness tests also consider inside directors, defined as the proportion of firm officers on the board. For a representative sample firm, the board is comprised of 9 directors, of whom $65 \%$ are independent, $14 \%$ are gray, and $21 \%$ are officers (including the CEO).

Local independent directors are independent directors employed at companies located within a sixty-mile radius of the sample firm, as a fraction of independent directors holding corporate jobs. For the average firm in our sample, about a third of independent directors are identified as holding executive positions, of which a third are employed at local firms. Executive experience contributes to a director's ability to effectively monitor and advise the CEO (Fich, 2005; Adams and Ferreira, 2007; Raheja, 2005). It is defined as the proportion of executive experts among independent board members (or outside directors, where specified). Executive experience includes current service as a chief executive officer, chief financial officer, chief operating officer, or inside director on another firm's board. ${ }^{5}$ Appendix A presents detailed variable definitions and data sources. Table 1 shows summary statistics for the main variables.

[Table 1]

\section{$\underline{\text { Local director labor markets }}$}

According to Guner et al. (2008), the most common outside director career is an active executive at another nonfinancial firm, followed by an active executive at a financial firm and non-corporate backgrounds. Similarly, in Linck et al. (2008b) corporate directors with

\footnotetext{
${ }^{4}$ RiskMetrics identifies gray directors based on proxy statements and disclosures of related transactions. Examples include executives of professional service providers; customers; suppliers; former employees of the firm or subsidiaries; directors designated by a significant shareholder or group (such as a union); majority holders; family members of executives; recipients of the firm's gifts; and interlocking directors (a director and executive of our firm sits on another board that has an executive and director who also sits on our board). Following NYSE listing standards, former employees can be reclassified as independent directors after three years. Excluding the few such cases from the independent director definition does not affect our results (the average proportion of independent directors declines by a tenth of a percent).

${ }^{5}$ Identification of directors with executive expertise is based on current executives within the RiskMetrics S\&P 1500 universe of companies, which does not cover very small or privately held firms. Compared to their peers at large firms, executives of small firms are less likely to be invited to join corporate boards, so excluding them should have little effect on our empirical results. As a way of evaluating the effect of excluding this group of executives, we also use a more comprehensive executive expertise measure based on BoardEx data in a robustness test.
} 
nonfinancial executive backgrounds are significantly more prevalent than financial, nonprofit, consultant or academic backgrounds. Therefore, our main measure of availability of prospective directors in the firm's vicinity is the density of nonfinancial firms within a sixty-mile radius of the sample firm (local director pool). ${ }^{6}$ Logs are used to address the right skewness of the densities. Since executives of direct competitors are unlikely to be asked to join the board due to competitive concerns about the release of proprietary information and anti-trust liability (price fixing), we exclude firms in the same four-digit SIC industry. In robustness tests, we expand the local pool definition to include all firms, use a hundred-mile radius, add Canadian firms, and, to account for the possibility that large firms are the primary source of directors, we exclude small firms from the local director pool.

We use firm headquarters locations reported in Compustat. Geographic coordinates are obtained from the US Census (2000) Gazetteer. Headquarters locations are generally chosen in the early life of a firm, many years prior to going public or making the board composition choices we examine, and typically for reasons unrelated to demand for a particular board structure. Thus, we treat firm location as predetermined and use the concentration of organizations' headquarters in the firm's vicinity as a source of exogenous variation. We perform robustness tests to examine the influence of infrequent headquarters relocations.

\section{Control variables}

We include a number of controls to capture other determinants of board independence suggested in prior work. Firm size has been linked to the presence of more outside directors (Boone et al., 2007; Coles et al., 2008; Linck et al., 2008a). Some tests include the degree of a

\footnotetext{
${ }^{6}$ This measure implicitly assumes that prospective directors holding top positions at other firms are generally concentrated at a firm's headquarters (which seems plausible as headquarters locations are likely to be most relevant for determining directors' cost of board participation) and the number of top executives available to serve on outside boards is comparable across firms. To address the possibility that firms of different size supply varying numbers of prospective directors, we redefine local director pools to contain only large companies in a robustness test in Table 4, Panel A, and find our results continue to hold.
} 
firm's business and geographic diversification, measured by the number of industry segments and a foreign segment indicator, respectively, as additional measures of the firm's operational complexity and the ensuing need for more outside experts on the board (Linck et al., 2008a).

Although independent directors have fewer conflicts of interest than insiders, they typically have less firm-specific knowledge (Fama and Jensen, 1983). Growth firms rely more on firm-specific knowledge, which results in fewer outside directors on the board (Coles et al., 2008; Linck et al., 2008a). We use sales growth, R\&D intensity, and intangible asset intensity (and to an extent, return volatility) to proxy for firm growth options. We also control for firm location in large and medium-sized cities, based on the US Census (2000), to capture the special characteristics of firms in areas with large population densities and business concentrations.

Some of our tests use controls for other governance and alignment mechanisms suggested in prior studies to be substitutes for or complements to board monitoring: the Gompers et al. (2003) G Index; institutional ownership, which captures institutional investor monitoring and governance preferences; and CEO ownership, which captures the degree of alignment of managerial and shareholder interests (Raheja, 2005). CEO characteristics may also affect board composition. More influential CEOs with longer tenure may require more board monitoring (Raheja, 2005). Alternatively, if tenure reflects ability, CEOs with longer tenure should require fewer outside experts on the board. Additionally, firms with older CEOs nearing retirement may add insiders to the board to facilitate internal succession (Linck et al., 2008a; Hermalin and Weisbach, 1998). Robustness tests add classified board and dual class shares indicators and an index of the strength of anti-takeover laws in the firm's state of incorporation from RiskMetrics. While firm-level governance and alignment indicators are used in prior work on boards as controls, they suffer from being determined simultaneously with board composition choices. 
Therefore, the coefficients associated with these controls cannot reliably be interpreted as causal effects, so we omit these controls to verify our main results. Finally, all specifications include three-digit SIC industry and year fixed effects to capture industry and temporal variation.

\section{$\underline{\text { Two-stage analysis }}$}

The crux of our analysis is based on a two-stage least squares examination of the relation between board independence and important firm decisions and outcomes (total CEO pay, the proportion of incentive pay in total pay, CEO turnover, firm value, and operating performance) to deal with major endogeneity concerns common in prior work. In the first stage, we predict the level of board independence by the size of the local director pool, our measure of interest, as well as industry median board independence (in the spirit of the John and Kadyrzhanova (2009)) and large and medium-sized city indicators. These variables affect board independence, but do not directly influence firm outcomes. We demonstrate the relevance of geographic predictors of board structure in the main board independence regressions.

In the second stage, firm performance and other variables are regressed on predicted board independence and a set of controls. ${ }^{7}$ The analysis excludes the top quartile of S\&P 1500 firms based on total asset size, for which local director markets are less likely to be a binding constraint, to focus on the smaller 3/4ths of S\&P 1500 firms. Since observations of a given firm can be autocorrelated, we use robust standard errors clustered at the firm level.

\section{Local director labor markets and board independence}

\footnotetext{
${ }^{7}$ One might be concerned that local director markets are capturing underlying variation in economic conditions, and therefore, affecting firm value directly. Conceptually, geographic pools in the area of the firm's location should not be directly related to individual valuations given the predetermined nature of firm location, the few headquarters relocations and, since the choice of initial location is made early in a firm's life for reasons such as access to suppliers, customers, and skilled labor, and not to secure prospective directors. In unreported tests we control for firm headquarter state in value regressions and obtain similar results; we also check that the local director pool instrument satisfies the orthogonality condition in value regressions, which further mitigates potential concerns about direct effects or validity of exclusion requirement.
} 
Figure 1 provides descriptive statistics supporting the premise that firms with access to larger local director markets draw a larger proportion of independent directors locally: in the full sample of S\&P 1500 companies the proportion of locally employed directors among independent directors with identifiable corporate positions is three times higher for companies drawn from the top quartile of local director pool size compared to companies from the bottom quartile.

Table 2 presents the main multivariate test of the relation between local director pools and a firm's percentage of independent directors on the board (in the full sample). We find the local supply of prospective directors has a strong effect on board independence. Firms near larger pools of prospective directors have a higher percentage of independent directors, after controlling for industry and year fixed effects (column I). In columns II and III, the result continues to hold after the inclusion of controls for other firm and CEO characteristics that have been linked to board independence in past work (size, growth, ROA, age, risk, asset tangibility, R\&D intensity, institutional ownership, the $\mathrm{G}$ index, and CEO ownership, age, and tenure).

\section{[Table 2]}

Figure 2 summarizes the economic magnitudes of these variables on board independence by taking one standard deviation changes in each variable, holding the other variables at their mean values. The local director pool effect is larger in magnitude than the individual effects of sales growth, risk, ROA, and CEO characteristics; comparable to the effects of asset tangibility and size; and is roughly half the size of CEO ownership and the G index of takeover defenses. Consistent with Coles et al. (2008), Denis and Sarin (1999), and Linck et al. (2008a), large firms have more independent directors. Young, growth firms have fewer independent directors, consistent with such firms having a greater need for firm-specific inside knowledge. Consistent with Coles et al. (2008), R\&D intensive firms have more independent directors on the board. 
Monitoring by institutional investors appears to complement board oversight, whereas higher managerial ownership and greater exposure to corporate control markets appear to serve as substitutes for strong board governance, although we are careful to interpret the relation as indicative of association rather than causally determined.

The relation between local director labor markets and board independence could vary by firm visibility. Directors internalize the costs of service on nonlocal boards, including transportation costs and opportunity costs of their time spent traveling to board meetings and keeping abreast of developments in these distant firms outside of board meetings (especially high if the firm encounters legal or financial difficulties). Prospective directors are more likely to overlook the costs of a nonlocal appointment if the firm is large and highly visible, since it offers greater reputational benefits, career building opportunities and networking benefits. ${ }^{8}$ Small firms typically hold the same number of board meetings (approximately seven per year), so a director's time commitments would appear to be roughly similar (Vafeas, 1999). Small firms are also more likely to face financial difficulties and financing constraints in the event of cash shortfalls. Although smaller firms could compensate directors for their lesser reputation benefits with higher pay, existing evidence indicates that director pay at smaller firms is significantly less (Linck et al., 2008b; Brick et al., 2006; Linn and Park, 2005). ${ }^{9}$ To the extent that potential independent directors are more willing to join nonlocal boards at large firms, large firms are much less constrained by the depth of the local director pool. By contrast, small and mediumsized firms appear to be significantly constrained by the local pool of prospective directors.

\footnotetext{
${ }_{9}^{8}$ For example, Masulis and Mobbs (2012) show that independent directors value directorships in larger firms more.

${ }^{9}$ In unreported tests, adding a control for director pay does not eliminate the local director pool effect, and there is no significant relation between local director pools and director pay.
} 
Recall that univariate tests in Table 1, Panel B show that smaller firms have a larger portion of independent directors who are locally based, consistent with the intuition that while high visibility firms have the luxury of tapping a wider, national director pool, less visible firms are constrained by the local supply of prospective directors. Multivariate evidence on this question is presented in Table 3. The local director pool has an economically strong and statistically significant effect on board independence for smaller firms, characterized by less overall visibility, but the local director pool is insignificant for large, well established firms. In summary, local director pools affect board independence at firms with low to moderate visibility (roughly three-quarters of the sample). High visibility firms do not appear constrained by the local supply of director talent. Intuitively, firm visibility is a plausible source of variation in the willingness of prospective directors to bear the costs of distant board meetings and thus, it captures the extent to which a firm is constrained to search locally for prospective directors.

\section{[Table 3]}

In the last set of tests reported in Table 3, we examine the relation between local director pools and board independence in the aftermath of recent governance reforms (the 2003 SarbanesOxley Act (SOX) and revised governance rules in the listing requirements of the NYSE and Nasdaq). More stringent board governance standards, including a majority of independent directors and independent director representation on key committees, could force non-compliant firms to expand their director search beyond their local director pools to accommodate this regulatory shock in the post-SOX period. We also note that this later period benefits from more advanced information and communications technology, which could make it easier for more distant directors to electronically attend board meetings and to more easily acquire firm-specific information from longer distances. However, we find that local director pools remain a 
significant factor in the appointment of independent directors, even as noncompliant firms increase board independence in the post-SOX period.

\section{Alternative measures of local director pools and robustness checks}

We examine the sensitivity of our finding to variable definitions, sample selection criteria, and additional controls. Our main local director pool measure includes executives at all nonfinancial US firms (outside the firm's own industry ${ }^{10}$ ) located within sixty miles of the firm in question. In Panel A of Table 4, we modify the local director pool definition for robustness. We start by varying the geographic boundaries of the local director pool, limiting it to the same county in column I, expanding it to a hundred-mile radius in column II, and augmenting it with Canadian firms in column III. Since firms may only want to hire independent directors with executive experience at larger or comparable size firms, we limit the local director pools to firms of similar or larger size in column IV and exclude small firms in column V. ${ }^{11}$ We include financial as well as non-financial firms from all industries in column VI. The local director pool coefficient remains positive and significant and retains its economic magnitude throughout these robustness tests. In an unreported test, inclusion of separate indicators for local director pools below and above sample median does not reveal significant nonlinearities.

\section{[Table 4]}

To account for possible alternative explanations, in Panel B of Table 4 we introduce additional controls. Geographic clusters of single industry firms studied by Almazan et al. (2007,

\footnotetext{
${ }^{10}$ A small minority of independent directors hold executive positions at another firm in the same industry (among independent directors with executive positions, only $2 \%$ work for a firm in the same four-digit SIC industry and just $3.5 \%$ - in the same threedigit SIC industry). This is likely due to concerns about potential conflicts of interest that may arise over proprietary information or strategic motives involving competitors.

${ }^{11}$ We exclude firms with assets below hundred million, which approximately corresponds to the first and second quintiles of assets in the full sample of nonfinancial firms (including firms with missing governance data) for our sample period.
} 
2010) do not explain the local director pool effect (column I). Also, the results cannot be attributed to omitted variation in regional economic profiles, demographics, or several major governance dimensions. Our main findings continue to hold after the addition of controls for local socioeconomic indicators such as population density, upper-income households, households drawing retirement income, college education per capita, and unemployment rate (column II), average statewide independent director representation on the board (column III). In columns IV-VI, we control for large and medium-sized city indicators, NYSE listing, classified boards, dual class shares, and multiple business and foreign segments. In unreported tests, we also control for profitability and investment opportunities in the state, director pay (without inference of causality), and a quadratic firm size term, and replace book value of assets with its market value as a measure of firm size.

Panel $\mathrm{C}$ of Table 4 uses alternative sample selection criteria and variable definitions. Since the proportion of independent directors is a fraction bounded between zero and one percent, in column I we report a logit regression estimate of board independence (see, e.g., Maddala (1983)). While the coefficients differ in magnitude, the local director pool coefficient retains its sign and significance. Firms headquartered in large cities are excluded in estimates reported in column II to verify that the local director pool is not merely capturing a big city effect. In unreported tests, we use local director pool lagged by one and two years, redefine board independence to exclude directors with $5 \%$ or greater stakes, include firms headquartered in Alaska and Hawaii (a handful of observations) and cluster errors both by firm and by year. The main effect remains statistically and economically significant. 


\section{$\underline{\text { Discussion of firm location choices }}$}

Consistent with prior research, we treat a firm's headquarters location as predetermined relative to current board decisions. Firms in our sample are far removed from a firm's startup/VC stage, with the average (median) firm publicly listed for 24 (18) years. However, for robustness, we exclude firms that go public during our sample period, leaving only firms for which the location decision is predetermined to mitigate the potential concern about the joint choice of location and governance (column V). The results remain qualitatively the same.

We also examine possible reasons for the initial location choice even when it predates our sample period. Prior research finds that location decisions are traditionally motivated by proximity to raw materials and other production inputs and minimization of transportation costs (for more discussion, see, e.g., Malecki (1985)). As the role of raw materials declines, location decisions are more likely to depend on proximity to skilled workers (e.g., Malecki, 1985; Almazan et al., 2007; Matouschek and Robert-Nicoud, 2005). Regional industry clusters may offer access to skilled workers or technology and industry specific information (see, e.g., Almazan et al. (2007, 2010)). To alleviate concerns that these effects could be driving our results, we control for local population density, college education rates, and industry clustering in Panel B of Table 4. In addition, since certain sectors and locations are more prone to regional industry clustering, in columns II-IV of Panel C we exclude firms located in large cities, the large industrialized states of California, Illinois, Massachusetts, and New York, and firms in technology intensive and automotive industries (the sample already excludes financials). The key results on local director pools remain qualitatively unaffected. 
Relocations are generally rare (e.g., Pirinsky and Wang, 2006 ${ }^{12}$ ). Our analysis of historical locations based on Compact Disclosure confirms this belief: the overwhelming majority of firms does not relocate; some move to a different city, but remain within sixty miles of their prior location; and exceedingly few firms relocate more than sixty miles away. However, for robustness we exclude firms that changed location based on historical location data obtained from the 1996-2004 Compact Disclosure datasets. These restrictions reduce the sample size, but our findings remain materially unchanged (columns VII-X of Panel C). As a further sensitivity check, we eliminate possible merger related relocations by excluding firms in the years they report acquisitions above five percent of book value of assets in our sample period (column VI). Based on our sensitivity analysis, relocations as well as factors commonly related to a firm's initial location choice fail to explain the local director pool effect on board oversight. As this robustness analysis yields very similar results, hereafter we report results for local director pools based on our main measure of the firm's location (Census Gazetteer coordinates of the county of the firm's headquarters).

\section{Other board characteristics}

To supplement our previous findings on the proportion of independent directors, we examine the proportion of gray and inside directors on the board in Panel A of Table 5. Firms with weak local director markets are likely to rely more heavily on gray directors to offset a lack of suitable independent director candidates. Although less effective as monitors, gray directors may be easier to recruit and they may offer valuable advice. As expected, we find that the proportion of gray directors is decreasing in the local director pool (column I). The fraction of

\footnotetext{
${ }^{12}$ They identify 118 relocating firms in 1992-1997 (for comparison, the full sample included 4,000-5,000 firms per year).
} 
inside directors is similarly decreasing in the size of the local director pool (column II), but at a much lower rate.

If proximity to a larger local pool of prospective directors leads firms to substitute independent directors for inside or gray directors, then board size should not be affected. If firms located near deeper local director pools add more independent directors while leaving other nonindependent directors on the board, then we should observe larger boards. Interestingly, we find that board size is not significantly related to local director pool (column III), consistent with firms substituting non-independent directors, when independent directors are difficult to recruit.

The prior analysis of board characteristics focuses on the proportion of outside directors on a firm's board. While it indicates the degree of board oversight, it is not a sufficient metric of the quality of such oversight or a board's ability to provide expert advice to management. Outside directors with executive expertise may be better able to challenge a CEO and thus, be crucial to improving shareholder wealth. Moreover, executives from other local firms comprise a significant proportion of independent directors and of the local pool of prospective directors. Thus, we explore the importance of the local pool of potential executive directors in Table 5, Panel B. The proportion of independent directors with executive experience is positively associated with the size of the local pool of executives (column I). This finding helps verify the hypothesized channel through which local pools of executives affect independent director recruitment. It also suggests that local director markets have implications for the level of board expertise - and arguably, the quality of board oversight - in addition to their effect on independent director representation. The results remains qualitatively the same when we focus on the pool of potential executives from similar-size or larger local firms (column II); include all 
outside directors (columns III-IV); or use BoardEx to construct a more comprehensive measure that includes executive experience at small publicly listed firms and private firms ${ }^{13}$ (column V).

To further analyze the channels through which local director pools affect board composition, we examine the representation of local executive experts on the board. Consistent with our hypothesis and univariate evidence in Figure 1, the proportion of local executives among independent and outside directors with executive experience is increasing in the local pool of executives (columns VI-VII). We obtain similar results for the proportion of local gray directors in column VIII. Further, average distance to an independent director's primary employer falls as the local director pool grows (column IX). We further note that representation of locally drawn independent and outside directors is highest for boards of small firms.

We also examine which types of firms supply local directors. We conjecture that large firms supply more prospective directors with executive expertise. We find that the proportion of executives with outside board seats at other local firms is higher for larger firms (column I). ${ }^{14}$ An executive of a large firm is more likely to sit on another local board and to hold more local board seats (columns II-III). Overall, large firms appear to act as suppliers of outside directors with executive expertise to smaller local firms (beyond the effect of large firms having more officers).

Corporate boards can benefit not only from general managerial experience, but also from independent directors with specialized expertise (see, e.g., Linck et al., 2008b). However, firms could be forced to forego certain types of valuable director expertise, such as technical, legal, or

\footnotetext{
${ }^{13}$ A greater proportion of directors with executive experience are identified using BoardEx data for the sample of boards since BoardEx lists executive affiliations at smaller firms, outside of S\&P1500, as well as at privately held (unlisted) companies. The proportion of executive experts among outside directors using BoardEx data rises to over sixty percent.

${ }^{14}$ Compared to all directors, insiders tend to hold fewer concurrent board appointments due to the demands of their main job, however, their board appointments are disproportionately concentrated among local firms (defined as firms within a sixty-mile radius). At an average firm in our sample, 31\% (14\%) insiders hold a concurrent appointment at another (local) firm. The average number of appointments at other (local) firms in our sample is $0.45(0.17)$ per insider. When all directors (inside, gray and independent) are considered, the average number of appointments at other (local) firms in our sample is $0.65(0.08)$ per director. Figures are based on an inside director's concurrent independent or gray director status on the board of another firm as reported by RiskMetrics.
} 
financial, when the local supply of such experts is limited. Of course, when specialized expertise is considered essential for a corporate board, representation of such experts could be less sensitive to local labor market conditions, as firms would search more intensively and potentially more widely for such expertise. This leaves us with an empirical question as to the importance of the local pool of director candidates with a particular expertise for a board's composition.

Tests of the effects of local pools of expertise are presented in Panel C. Consistent with a local labor supply effect, the proportion of outside directors with technology expertise increases in the size of the local pool of such prospective directors. Further, a board's overall legal expertise is positively related to the local density of main offices of major law firms, a proxy for the local supply of prospective directors with legal experience. At the margin, the board's level of financial expertise is positively related to the density of financial institution headquarters in a firm's vicinity, which is a proxy for the local availability of potential directors with financial knowledge. We conclude that composition of a firm's board in terms of independent director expertise is significantly related to the local pool of such expertise.

\section{The effects of board independence on CEO incentives and firm performance}

A number of prior studies report evidence that greater representation of outside directors on boards is associated with shareholder wealth gains (e.g., Gompers et al., 2003; Cremers and Nair, 2005; Bebchuk and Cohen, 2005; Masulis and Mobbs, 2011; Rosenstein and Wyatt, 1990; Brickley et al., 1994). Other prior empirical studies find mixed or insignificant evidence on the effect of independent director representation on performance or shareholder wealth (e.g., Bhagat and Black, 2002; Hermalin and Weisbach, 1991; Klein, 1998; Agrawal and Knoeber, 1996; Yermack, 1996; see, e.g., Adams et al. (2010) and Hermalin and Weisbach (2003) for a detailed 
survey). ${ }^{15}$ Moreover, many well known researchers have raised concerns about endogeneity of board composition and the challenges to attributing causation to any observed associations of board independence to firm decisions and outcomes (e.g., Hermalin and Weisbach, 1998, 2003; Adams et al., 2010; Boone et al., 2007; Coles et al., 2008).

There are several common criticisms of the evidence in existing board independence studies. First, omitted variable bias arises when certain characteristics not captured by the model are correlated with both firm value and board independence. For example, growth firms, which tend to have higher valuations, may appoint more insiders due to the high costs of conveying proprietary information to outsiders, whereas mature firms, which tend to have lower valuations, may appoint outsiders to overcome their greater agency conflicts. Second, reverse causality concerns arise if well performing firms, which have fewer agency problems, have less need for outside director monitoring, whereas poorly performing firms need more outsiders on the board (see, e.g., Hermalin and Weisbach, 1988b; Coles, Daniel and Naveen, 2008). Unless proper identification is used, these confounding effects can dominate the positive effect of independence on firm value and performance and bias the relations toward insignificance.

Endogeneity concerns cast some serious doubts on the ability of OLS estimation to establish causation. A recent study by Nguyen and Nielsen (2010) seeks to address this endogeneity concern by looking at market reactions to sudden director deaths, a type of unexpected exogenous shock to board composition. Although the approach yields interesting insights consistent with our findings that independent directors add to firm value, it is limited to a small sample of 229 sudden deaths of directors, including 108 independent directors;

\footnotetext{
${ }^{15}$ Bar-Hava and Segal (2010) find poor performance after independent director resignations. However, as Adams et al. (2010) and Hermalin and Weisbach (1998) argue, independent director presence on the board is endogenous to performance. Also, as Aggrawal and Chen (2011) and Dewally and Peck (2010) indicate, director resignations may be related to boardroom conflicts between directors and management over board performance and agency problems. In light of this, the interpretation of the effects of independent director resignations on performance faces significant hurdles.
} 
moreover, a large majority of the deceased independent directors are replaced with new independent directors within a year and there can be some offsetting effects associated with market expectations about their expected replacements.

Given the controversies surrounding the causal relation between board independence and shareholder wealth, we offer new evidence much less susceptible to endogeneity concerns. Specifically, we exploit the exogenous variation in the density of local labor markets for director talent, documented in the previous tables, to instrument for board independence. We then employ this instrument to estimate the effects of board independence on CEO compensation and turnover, and firm value and operating performance. All our regression models include industry and year fixed effects to filter out industry variation and any general time trends. We also include a number of controls to account for differences in firm characteristics that could be related to a firm's bottom line outcomes.

A limited pool of local director talent imposes more binding external constraints on board selection in small and medium-sized firms, as shown earlier in this study. Thus, we concentrate our attention on this large subsample (75\% of the full sample of S\&P 1500 firms) and employ a two-stage instrumental variables model. In the first stage, we use variation in local director pools and other controls to predict board independence. Then in the second stage regressions, we reexamine the effects of board independence on the quality of important board decisions, such as CEO pay and turnover, and firm performance outcomes, measured by operating performance and Tobin's Q. This evidence is presented in Tables 6-9 respectively.

\section{[Table 6]}

Existing studies report that firms with more independent boards use higher proportions of incentive pay, presumably to better motivate managers (e.g., Mehran, 1995). We reexamine the 
association between board composition and CEO pay using local availability of prospective directors as a source of external variation in board structure. In Table 6, column I, we find clear evidence that more independent boards use a larger proportion of equity based compensation in total CEO compensation. All else the same, a one standard deviation increase in board independence results in a $5.7 \%$ increase in the percent of stock option pay in total CEO pay. The result holds with a broader definition of performance pay that combines stock options and restricted stock grants (column II). In contrast, there are no significant effects on total CEO pay. Inclusion or omission of controls for CEO-chairman duality, industry clusters, a sunshine index, industry median pay level, capital expenditure and R\&D levels as a percent of assets, industry segments, major foreign operations or a foreign sales segment, and a technology intensive sector indicator does not change the result. Thus, while independent boards strengthen CEO incentives through a greater weight on equity compensation, we do not find evidence of board independence effects on the overall level of CEO pay. So interestingly, the increase in CEO risk-bearing caused by enhanced performance based pay does not appear to be compensated by higher executive pay.

We also examine the relation between board independence and CEO turnover, including both voluntary and forced. Since firms commonly disguise forced turnover when reporting CEO changes (Weisbach (1988), Jenter and Lewellen (2010)), the distinction between forced and voluntary departures is difficult to decipher in practice. Nevertheless, some instances of CEO turnover are clearly unrelated to performance, namely CEO deaths. Since they do not offer evidence of boards disciplining CEOs, we exclude these relatively infrequent CEO turnover 
cases. ${ }^{16}$ We find that the proportion of independent directors is positively associated with CEO turnover. Independent director representation is also associated with marginally higher sensitivity of turnover to poor performance (a negative stock return interaction term, significant at ten percent). All else the same, a twenty-percent increase in board independence raises the likelihood of turnover by $4 \%$. Thus, we find new evidence free of endogeneity concerns that more independent directors lead to significantly stronger CEO performance incentives, both in terms of compensation and retention. In unreported tests, we find CEOs at firms with independent boards are characterized by shorter tenure, which suggests higher CEO turnover.

In Table 7 we examine the effect on the firm's profitability and operating performance, measured by ROA and operating cash flow scaled by total assets. The proportion of independent directors has a significant positive effect on operating performance. The documented effects are economically important. Holding other factors constant, a one standard deviation (17\%) increase in board independence predicts a $1.14-1.65 \%$ increase in ROA. As a point of comparison, median ROA is $14 \%$ and a one standard deviation of ROA is $11 \%$, so the effect of board independence is economically significant in absolute terms. In relative terms, the magnitude of the board independence effect on ROA exceeds or is comparable to that of other determinants, except for firm risk. Operating cash flow yields similar effects (a $1.36-1.77 \%$ increase in response to a one standard deviation increase in board independence, all else equal). By comparison, ordinary least squares estimates yield insignificant effects or ones close to zero.

[Table 7]

\footnotetext{
${ }^{16}$ One might ask if local director pool density captures executive labor market competition and affects CEO turnover or pay or the bottom line directly. However, the instrument meets the orthogonality condition (the effect of local director pool is only through greater board independence).
} 
In Table 8, we evaluate whether predicted board independence has significant effects on firm value (measured by market-to-book ratios at fiscal year-end). ${ }^{17}$ We find that the proportion of independent directors on the board has significant positive effects on firm value. The effect is also economically meaningful. All else the same, a one standard deviation increase in the proportion of independent directors on a firm's board results in a $0.15-0.17$ rise in a firm's market-to-book ratio (as a point of comparison, the median market-to-book ratio is 1.66 and the standard deviation is 1.44). In terms of magnitude, the board composition effect is larger than or comparable to the other determinants of the market-to-book ratio.

\section{[Table 8]}

In Table 9 we examine the effects of board size in addition to the effects of independence. After controlling for board independence, board size is not statistically significant. Next, it is also possible that the proportion of local directors has a value effect above and beyond the impact of independent director representation. Local directors could be better informed as monitors, or they could be less effective due to being more socially dependent on the CEO. However, we find that local directors per se do not have a significant effect, while independent director representation remains significant. Although deeper local director pools may facilitate local hiring, their key effect is to facilitate the recruiting of more independent directors, which enhances firm performance and shareholder value.

\section{[Table 9]}

\section{$\underline{\text { Robustness and two-stage least squares estimates }}$}

Following prior work, we include standard controls for firm size, age, growth opportunities, risk, G index, institutional ownership, and CEO characteristics. The G Index

\footnotetext{
${ }^{17}$ Market-to-book is defined as fiscal year end market value divided by book value, similar to prior work. In untabulated results, the effects of director independence are similar if we divide by lagged book value.
} 
enters with a negative sign in firm value regressions, consistent with Gompers et al. (2003). Institutional ownership is associated with better operating performance and firm value. CEO tenure, a proxy for managerial quality, is positively associated with firm value and performance. In some specifications we added other controls suggested in prior studies of firm value (dual class firm indicator and dividend payout), which were not significant but did not affect the relation of board independence and firm value.

Although the use of an extensive set of controls mitigates omitted variable concerns, some variables, such as CEO ownership and other managerial characteristics, as well as the firm's risk and R\&D choices, may be determined simultaneously with value and performance. Therefore, in each table we also estimate a parsimonious specification that omits controls that and uses an index of anti-takeover laws in the state of incorporation instead of the firm-level index of takeover defenses. The main results continue to hold, yielding even stronger economic impact and statistical significance.

One might be concerned that local industry clusters can create an alternative channel for firm valuation or performance effects. In addition to using industry fixed effects to filter out time-invariant heterogeneity in firm performance, we also control for the local density of firms in the same industry to account for possible competitive or knowledge spillover effects of local industry peers on firm performance. The addition of this control does not explain our results.

The relevance of local director pools for board composition is confirmed by Tables 2-4 and first-stage statistics reported in Tables 6-9 (full first stage estimates are in Appendix B and are consistent with the evidence in Table 3 and Table 4, Panel C). The instrument's excludability is economically intuitive: local director labor markets are unlikely to affect firm value, performance or CEO pay or turnover directly, only through board composition. Since firm 
relocations are very infrequent, location can be viewed as a predetermined characteristic, exogenous to independent director selection. Our findings are qualitatively unchanged after excluding relocations. Section 2 provided further discussion of the instrument.

\section{Quantifying the effects of endogeneity on board independence estimates}

One of our main contributions is providing evidence of the impact of board independence on various firm outcomes from a large firm panel after correcting for endogeneity. Below we take a two-prong approach to quantify the effects of endogeneity on board independence estimates. Though our analysis and contexts differ, a similar discussion of endogeneity concerns and the effects of endogeneity adjustments on coefficient estimates is found in the Edmans, Goldstein and Jiang (2012) study of market discounts and takeovers.

First, for the purposes of comparison with two-stage estimates, we report ordinary least squares estimates of the effects of board independence, which do not adjust for endogeneity, at the bottom of each table. Consistent with prior evidence based on OLS regressions, independent boards do not significantly improve firm value or performance (see, e.g., Adams, Hermalin, and Weisbach (2010) and Hermalin and Weisbach (2003) for a detailed survey). Moreover, in most cases, two-stage estimates differ substantially in terms of magnitudes, signs and significance from OLS estimates. Estimates of board independence effects on firm valuation change from a near zero statistically insignificant coefficient in the OLS regression to a statistically significant positive 0.009-0.010 coefficient in two-stage regressions (a one standard deviation increase in board independence predicts a $0.15-0.17$ increase in market-to-book). In the performance regressions, OLS estimates of board independence coefficients are insignificant and close to zero (or negative, in one ROA specification), whereas two-stage estimates are highly significant and positive, 0.07-0.10 (a one standard deviation increase in board independence predicts a 1.14-1.65 
percent increase in ROA). In the turnover regressions, OLS estimates of board independence effects are insignificant, while two-stage regressions reveal significantly greater frequency of CEO turnover in the presence of independent boards. In the CEO incentive pay regressions, both OLS and two-stage estimates of board independence are positive, but two-stage estimates are significantly larger in size (rising from around 0.07 to around 0.3 ). Finally, there is no significant board independence effect on total pay, in either the OLS or 2SLS specifications.

Second, we perform a formal Hausman test of the differences between ordinary least squares and two-stage estimates of board independence. A significant test statistic indicates that the null hypothesis of the two vectors of coefficient estimates being similar is rejected, which would support the concern that board independence is an endogenous variable. For almost all of of our specifications, the tests reveal significant endogeneity in the board independence estimates (at ten percent or better level), which is corrected in two-stage estimation.

Both preliminary analysis and formal tests reveal significant differences in under OLS and 2SLS board independence coefficient estimates. Endogeneity present in OLS results weakens the estimated economic and statistical impacts of board independence on firm performance. Thus, adequately adjusting for the endogeneity of board independence is a necessary and important step to a clearer understanding of how board independence affects shareholder wealth.

Our findings are consistent with the empirical prediction of Hermalin and Weisbach (1998) that firms increase board independence in response to poor performance. They argue that periods of strong performance strengthen the belief about the CEO's ability, resulting in greater CEO bargaining power, which is associated with decreases in board independence. By contrast, poor performance reduces the CEO's bargaining power and forces the CEO to accept the 
addition of independent directors to the board. When this reverse causality effect of poor performance on increased independence is combined with the direct effect of board structure on performance, OLS estimates become uninformative. Endogeneity of board composition has led many studies to find insignificant or mixed evidence of board independence effects on various firm bottom-line variables. When we isolate the direct effect of board independence on performance in a two-stage setting, we obtain significant positive coefficients.

\section{Conclusions}

We examine how local director labor markets affect board composition choices. We find that small and medium-sized firms, which have low visibility, are most dependent on local director labor markets. By contrast, the largest firms (top quartile) are able to recruit directors nationally. Intuitively, prospective directors appear willing to trade off the costs of distance and the benefits of affiliation with a large, established firm.

We find that the supply of potential directors in the local labor market strongly affects board composition for all but the largest S\&P 1500 firms. For instance, one third of independent directors holding executive positions on average are employed locally. Access to larger local pools of prospective directors increases the fraction of independent directors and reduces the fraction of gray and inside directors on a board. This suggests that firms struggling to recruit independent directors fall back on appointing gray and inside directors. At firms located near larger local pools of prospective directors, a significantly larger fraction of independent directors are drawn locally. In terms of economic importance, this effect exceeds or equals the individual effects of sales growth, risk, tangibility, firm size and major CEO traits. To corroborate the channel through which the local director pool influences board composition, we examine the 
proportion of local executives sitting as independent directors on boards and find that it similarly increases in the size of the local pool of executive directors.

Prior studies of board independence effects on firm value report mixed or weak results, in part due to the endogeneity of board composition choice, as firms tend to increase board independence in response to performance declines. Using our finding that local pools of prospective directors are a powerful predictor of board independence, we reexamine the important question of how board independence is related to a firm's bottom line outcomes. We focus on the firms that are most constrained by the local pool of prospective directors due to their lack of visibility and prestige. Using this supply constraint on director hiring for identification, we find that board independence has significant positive effects on firm value, operating performance, CEO turnover, and the proportion of equity based pay, but no effect on total CEO compensation. We find a one standard deviation increase in board independence results in a $1.3 \%$ rise in ROA and a 0.17 rise in the market-to-book ratio, all else equal.

Overall, local labor markets for prospective director talent are an important determinant of board composition, in spite of the availability of long distance travel and information technology. Geographic distance negatively affects the willingness of prospective directors to serve on boards, especially those employed in full-time executive and professional positions that place heavy demands on their time. Thus, the supply effect of local director pool has strong influence on board composition, and future research on boards should take this into account. 


\section{References}

Adams, R., Ferreira, D., 2007. A theory of friendly boards. Journal of Finance 62(1), 217-250.

Adams, R., Hermalin, B., Weisbach, M., 2010. The role of boards of directors in corporate governance: A conceptual framework and survey. Journal of Economic Literature, 48(1), 58-107.

Agrawal, A., Chen, M., 2011. Boardroom brawls: an empirical analysis of disputes involving directors. Working paper.

Agrawal, A., Knoeber, C., 1996. Firm performance and mechanisms to control agency problems between managers and shareholders. Journal of Financial and Quantitative Analysis 31(3), 377-397.

Alam, Z., Chen, M., Ciccotello, C., Ryan, C., 2011. Does the location of directors matter? CEO influence, information acquisition and board decisions. Working paper.

Almazan, A., De Motta, A., Titman, S., 2007. Firm location and the creation and utilization of human capital. Review of Economic Studies 74, 1305-1327.

Almazan, A., De Motta, A., Titman, S., Uysal, V., 2010. Financial structure, liquidity and firm locations. Journal of Finance 65(2), 529-563.

Bae, K.-H., Stulz, R., Tan, H., 2008. Do local analysts know more? A cross-country study of the performance of local analysts and foreign analysts. Journal of Financial Economics 88(3), 581-606.

Baginski, S., Hassell, J., Kimbrough, M., 2004. Why do managers explain their earnings forecasts? Journal of Accounting Research 42(1), 1-29.

Bar-Hava, K., Segal, D., 2010. Do outside directors tell the truth, the whole truth, and nothing but the truth when they resign? Working paper.

Bebchuk, L., Cohen, A., 2005. The costs of entrenched boards. Journal of Financial Economics 78(2), 409-433.

Becker, B., Ivkovic, Z., Weisbenner, S., 2011. Local dividend clienteles. Journal of Finance 66(2), 655-683.

Bengtsson, O., and A. Ravid, 2011. Geography and style in private equity contracting: evidence from the US venture capital market. Working paper.

Bhagat, S., Black, B., 2002. The non-correlation between board independence and long-term firm performance. Journal of Corporation Law 27, 231-273

Boone, A., Field, L. C., Karpoff, J., Raheja, C., 2007. The determinants of corporate board size and composition: An empirical analysis. Journal of Financial Economics 85(1), 66-101.

Bouwman, C., 2011. Corporate governance propagation through overlapping directors. Review of Financial Studies 24(7), 2358-2394.

Brennan, M., Cao, H., 1997. International portfolio investment flows. Journal of Finance 52(5), $1851-1880$.

Brick, I., Pamon, O., Wald, J. K., 2006. CEO compensation, director compensation, and firm performance: Evidence of cronyism? Journal of Corporate Finance 12(3), 403-423.

Brickley, J., Coles, J., Terry, R., 1994. Outside directors and the adoption of poison pills. Journal of Financial Economics 35(3), 371-390.

Brickley, J., Linck, J. A., Smith, C. W., 2003. Boundaries of the firm: evidence from the banking industry. Journal of Financial Economics 70(3), 351-383.

Coles, J., Daniel, N., Naveen, L., 2008. Boards: Does one size fit all? Journal of Financial Economics 87(2), 329-356.

Coval, J., Moskowitz, T., 1999. Home bias at home: Local equity preference in domestic portfolios. Journal of Finance 54(6), 2045-2073.

Coval, J., Moskowitz, T., 2001. The geography of investment: Informed trading and asset prices. Journal of Political Economy 109(4), 811-841. 
Cremers, M., Nair, V., 2005. Governance mechanisms and equity prices. Journal of Finance 60(6), 2859-2894.

Denis D., Sarin, A., 1999. Ownership and board structures in publicly traded corporations. Journal of Financial Economics 52(2), 187-223.

DeWally, M., Peck, S., 2010. Upheaval in the boardroom: outside director public resignations, motivations, and consequences. Journal of Corporate Finance 16(1), 38-52.

DeYoung, R., Glennon, D., Nigro, P., 2008. Borrower-lender distance, credit scoring, and loan performance: evidence from informational-opaque small business borrowers. Journal of Financial Intermediation 17(1), 113-143.

Edmans, A., Goldstein, I., Jiang, W., 2012. The real effects of financial markets: the impact of prices on takeovers. Journal of Finance 67(3), 933-971.

Fama, E., Jensen, M., 1983. Separation of ownership and control. Journal of Law and Economics 26(2), 301-325.

Ferris, S., Jagannathan, M., Pritchard, A., 2003. Too busy to mind the business? Monitoring by directors with multiple board appointments. Journal of Finance 58(3), 1087-1111.

Fich, E., 2005. Are some outside directors better than others? Evidence from director appointments by Fortune 1000 firms. Journal of Business 78(5), 1943-1971.

Gompers, P., Ishii, J., Metrick, A., 2003. Corporate governance and equity prices. Quarterly Journal of Economics 118(1), 107-155.

Guner, B., Malmendier, U., Tate, G., 2008. Financial expertise of directors. Journal of Financial Economics 88(2), 323-354.

Guo, L., Masulis, R., 2012. Board structure and monitoring: new evidence from CEO turnover. Working paper.

Hermalin, B., Weisbach, M., 1991. The effects of board composition and direct incentives on firm performance. Financial Management 20(4), 101-112.

Hermalin, B., Weisbach, M., 1998a. Endogenously chosen boards of directors and their monitoring of the CEO. American Economic Review 88(1), 96-118.

Hermalin, B., Weisbach, M., 1988b. The determinants of board composition. Rand Journal of Economics 19(4), 95-112.

Hermalin, B., Weisbach, M., 2003. Boards of directors as an endogenously determined institution: a survey of the economic literature. FRBNY Economic Policy Review 9, 726.

Ivkovic, Z., Weisbenner, S., 2005. Local does as local is: Information content of the geography of individual investors' common stock investments. Journal of Finance 55(1), 267-306.

Jenter, D., Lewellen, K., 2010. Performance-induced CEO Turnover. Working paper.

John, K., Kadyrzhanova, D., 2009. Relative governance. Working paper.

John, K., Knyazeva, A., Knyazeva, D., 2011. Does geography matter? Firm location and corporate payout policy. Journal of Financial Economics 110(3), 533-551.

Kang, J.-K., Kim, J.-M., 2008. The geography of block acquisitions. Journal of Finance 63, 2817-2858.

Kang, J.-K., Stulz, R.M., 1997. Why is there home bias? An analysis of foreign equity portfolio ownership in Japan. Journal of Financial Economics 46(1), 3-28.

Kedia, S., Panchapagesan, V., Uysal, V., 2008. Geography and acquirer returns. Journal of Financial Intermediation 17(2), 256-275.

Klein, A., 1998. Firm performance and board committee structure. Journal of Law and Economics 41(1), 275-304.

Landier, A., Nair, V., Wulf, J., 2009. Trade-offs in staying close: Corporate decision making and geographic dispersion. Review of Financial Studies 22(3), 1119-1148.

Lerner, J., 1995. Venture capitalists and the oversight of private firms. Journal of Finance 50(1), 301-318. 
Linck, J., Netter, J., Yang, T., 2008a. The determinants of board structure. Journal of Financial Economics 87(2), 308-328.

Linck, J., Netter, J., Yang, T., 2008b. The effects and unintended consequences of the SarbanesOxley Act on the supply and demand for directors. Review of Financial Studies 22(8), 3287-3328.

Linn, S., Park, D., 2005. Outside director compensation policy and the investment opportunity set. Journal of Corporate Finance 11(4), 680-715.

Loughran, T., Schulz, P., 2005. Liquidity: urban versus rural firms. Journal of Financial Economics 78(2), 341-374.

Loughran, T., Schulz, P., 2006. Asymmetric information, firm location, and equity issuance, Working paper.

Maddala, G., 1983. Limited Dependent and Qualitative Variables in Econometrics. Cambridge University Press, Cambridge, England.

Malecki, E., 1985. Industrial location and corporate organization in high technology industries. Economic Geography 61(4), 345-369.

Malloy, C., 2005. The geography of equity analysis. Journal of Finance 60(2), 719-755.

Masulis, R., Mobbs, S., 2011. Are all inside directors the same? Journal of Finance, 66(3), 823872.

Masulis, R., Wang, C., Xie, F., 2011. Are foreign directors valuable advisors or ineffective monitors? Working paper.

Matouschek, N., Robert-Nicoud, F., 2005. The role of human capital investments in the location decision of firms. Regional Science and Urban Economics 35(5), 570-583.

Mehran, H., 1995. Executive compensation structure, ownership, and firm performance. Journal of Financial Economics 38(2), 163-184.

Nguyen, B.D., Nielsen, K., 2010. The value of independent directors: evidence from sudden deaths. Journal of Financial Economics 98(3), 550-567.

Perry, T., Peyer, U., 2005. Board seat accumulation by executives: A shareholder's perspective. Journal of Finance 60(4), 2083-2123.

Pirinsky, C., Wang, Q., 2006. Does corporate headquarters location matter for stock returns? Journal of Finance 61(4), 1991-2015.

Raheja, C., 2005. Determinants of board size and composition: A theory of corporate boards. Journal of Financial and Quantitative Analysis 40(2), 283-306.

Rosenstein, S., Wyatt, J., 1990. Outside directors, board independence, and shareholder wealth. Journal of Financial Economics 26(2), 175-191.

Shivdasani, A., Yermack, D., 1999. CEO involvement in the selection of new board members: an empirical analysis. Journal of Finance 54(5), 1829-1853.

Vafeas, N., 1999. Board meeting frequency and firm performance. Journal of Financial Economics 53(1), 113-142.

Wan, H., 2008. Are local directors better monitors? Working paper.

Weisbach, M., 1988. Outside directors and CEO turnover. Journal of Financial Economics 20(12), 431-460.

Yermack, D., 1996. High market valuation of companies with a small board of directors. Journal of Financial Economics 40(2), 185-211.

Yermack, D., 2004. Remuneration, retention, and reputation incentives for outside directors. Journal of Finance 59(5), 2281-2308. 


\section{Fig. 1. Local director markets and the presence of local independent directors on boards}

Mean local independent directors (\%) (on the Y-axis) by Local director pool quartile. Local Independent Directors (\%) is the percent of independent directors holding corporate executive positions who are locally employed (within a sixty-mile radius of the firm's headquarters). For consistency, only observations where name and headquarters location of the company of outside employment is known were used. Variable definitions and sample selection criteria are presented in Appendix A.

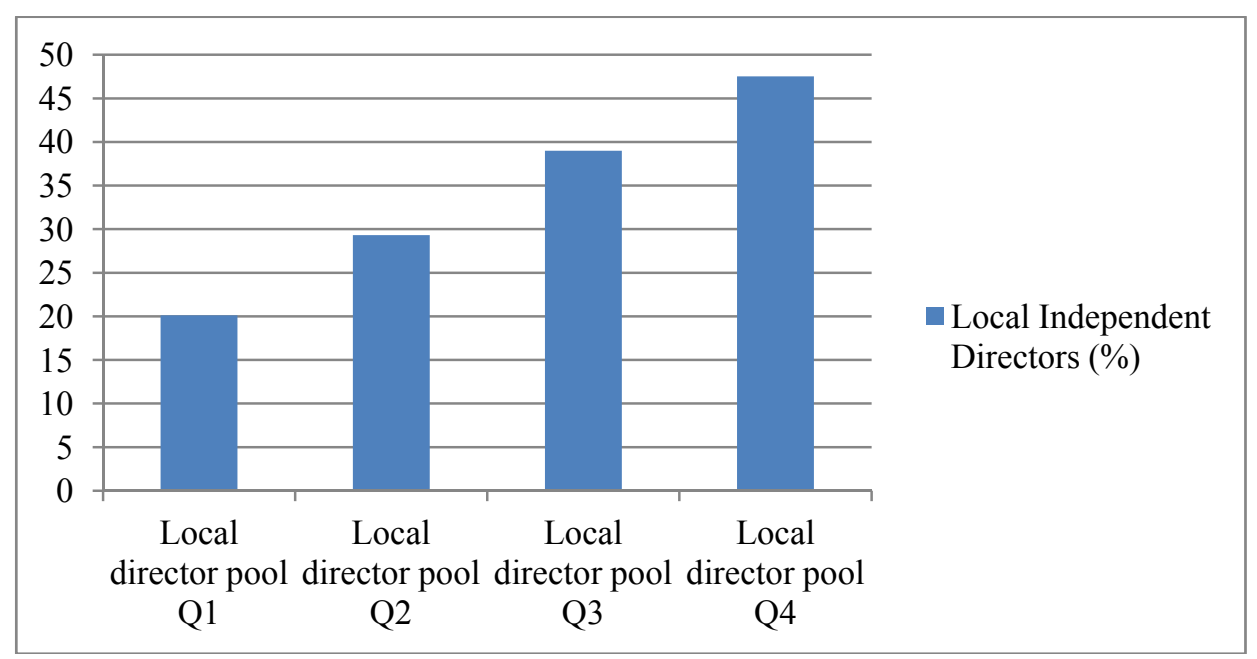

\section{Fig. 2. The economic significance of local director markets relative to other determinants of board independence}

Economic effect of a one standard deviation increase in the $\mathrm{X}$ variable on Independent directors (\%). Economic effects are computed based on coefficient estimates from Table 2, column III and standard deviations of right-hand-side variables reported in Table 1. For each determinant of Board independence, the Y-axis displays the expected change in independent director representation on the board, Independent Directors (\%), in response to a one standard deviation increase in the determinant, holding other determinants constant.

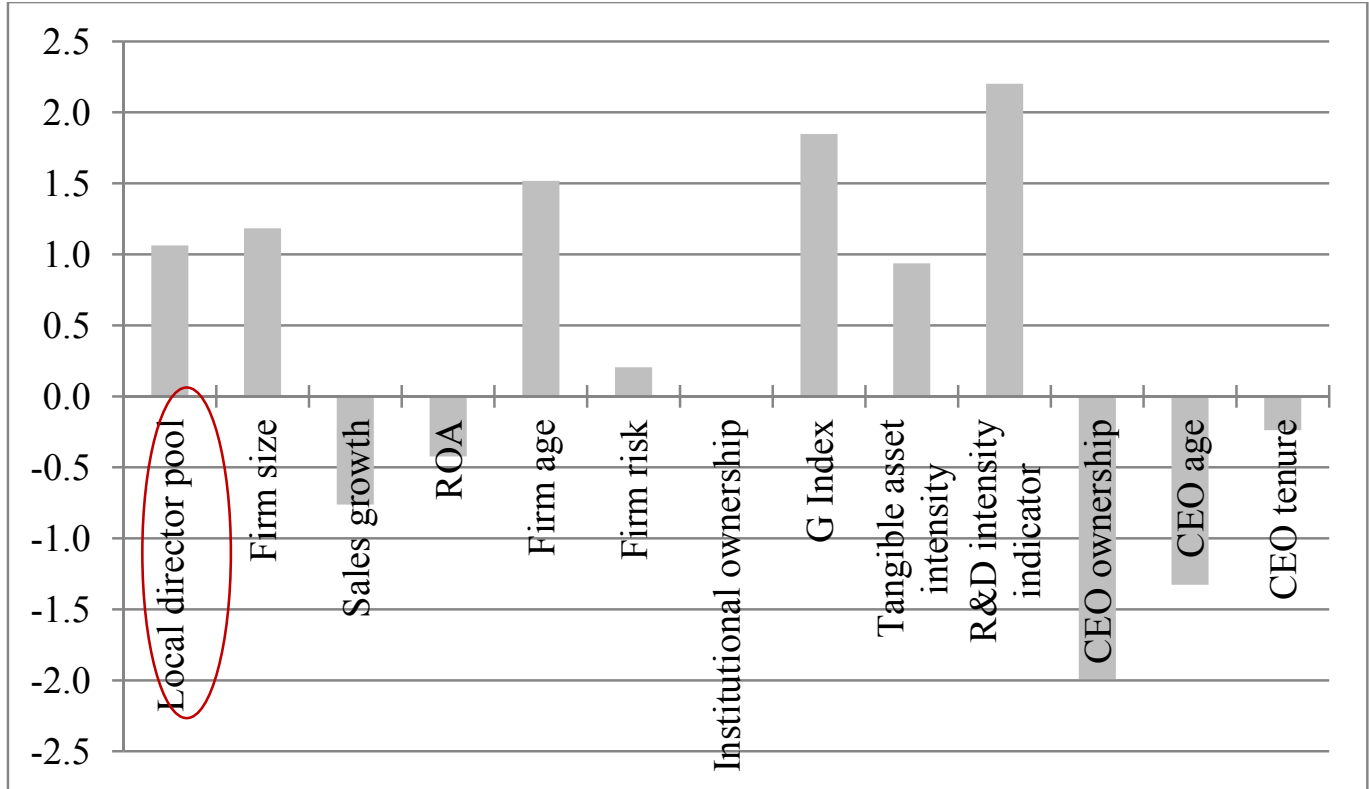




\section{Table 1. Summary statistics of the main variables}

We use the 1996-2006 sample of Compustat/CRSP firms that have RiskMetrics corporate governance measures, 13f institutional holdings, and Execucomp data available, excluding firms with total assets below twenty million, regulated financial and utility firms (SIC codes 6000-6999 and 4900-4999), and firms headquartered outside the continental US. Variable definitions are presented in Appendix A.

Panel A presents summary statistics for the main sample. Panel B examines representation of local directors on corporate boards across subsamples. Local Independent/Gray/Outside directors (\%) is the percent of these respective directors employed within a sixty-mile radius of the firm's headquarters among independent/gray/outside directors respectively with identified corporate positions. For consistency, only observations where name and headquarters location of the company of outside employment is known were used. Firms size is measured by total book assets. Two-sided t-tests of differences in means are performed; statistical significance at $1 \%, 5 \%$, and $10 \%$ levels is denoted with ${ }^{* * *}$, ${ }^{* *}$, and ${ }^{*}$, respectively.

\begin{tabular}{|c|c|c|c|c|c|}
\hline Panel A: Summary & Statistics & Obs & Mean & Med & SD \\
\hline Board Characteristics: & Independent Directors (\%) & 9693 & 65.14 & 66.67 & $\overline{17.49}$ \\
\hline & Inside Directors (\%) & 9693 & 20.88 & 16.67 & 11.39 \\
\hline & Gray Directors (\%) & 9693 & 13.98 & 11.11 & 13.83 \\
\hline & Board Size & 9693 & 2.17 & 2.20 & 0.27 \\
\hline & Board Size [num] & 9693 & 9.11 & 9.00 & 2.48 \\
\hline & Local Independent Directors (\%) & 3365 & 34.03 & 0.00 & 43.34 \\
\hline & Local Gray Directors (\%) & 785 & 49.64 & 50.00 & 48.85 \\
\hline & Local Outside Directors (\%) & 3842 & 36.76 & 0.00 & 43.92 \\
\hline & Insiders with Local Directorships (\%) & 9628 & 13.54 & 0.00 & 30.20 \\
\hline & Executive Expertise (\%) & 8217 & 33.35 & 33.33 & 23.42 \\
\hline Local Director Pool: & Local director pool & 9693 & 3.75 & 4.04 & 1.65 \\
\hline & Local director pool [num] & 9693 & 105 & 56 & 116 \\
\hline & Local director pool (similar or larger size) & 9693 & 2.65 & 2.83 & 1.46 \\
\hline & Local director pool (similar or larger size) [num] & 9693 & 32 & 16 & 44 \\
\hline Firm Characteristics: & Firm size & 9693 & 7.32 & 7.18 & 1.41 \\
\hline & Firm size $[\mathrm{mln}]$ & 9693 & 5571 & 1312 & 18219 \\
\hline & Sales growth & 9693 & 0.12 & 0.08 & 0.28 \\
\hline & ROA & 9693 & 0.14 & 0.14 & 0.11 \\
\hline & Market-to-book ratio & 9693 & 2.12 & 1.66 & 1.44 \\
\hline & Dividend yield & 9693 & 0.96 & 0.33 & 1.35 \\
\hline & G Index & 9693 & 9.22 & 9.00 & 2.60 \\
\hline & Institutional ownership & 9693 & 67.83 & 69.72 & 17.93 \\
\hline & Firm age & 9693 & 2.93 & 2.94 & 0.79 \\
\hline & Firm age [years] & 9693 & 24.12 & 18.00 & 19.33 \\
\hline & Firm risk & 9693 & 2.57 & 2.26 & 1.28 \\
\hline & Tangible asset intensity & 9693 & 0.30 & 0.24 & 0.21 \\
\hline & $\mathrm{R} \& \mathrm{D}$ intensity indicator & 9693 & 0.53 & 1.00 & 0.50 \\
\hline CEO Characteristics: & CEO ownership & 9693 & 2.34 & 0.31 & $\overline{5.62}$ \\
\hline & CEO age & 9693 & 0.09 & 0.00 & 0.29 \\
\hline & CEO tenure & 9693 & 1.74 & 1.79 & 0.90 \\
\hline & CEO tenure [years] & 9693 & 7.33 & 5.00 & 7.61 \\
\hline & Incentive/total CEO pay & 9640 & 36.18 & 35.25 & 28.96 \\
\hline & Incentive/total CEO pay (II) & 9640 & 43.99 & 47.20 & 29.09 \\
\hline & Total CEO pay & 9499 & 3.27 & 1.80 & 4.66 \\
\hline & CEO turnover & 9481 & 0.12 & 0.00 & 0.32 \\
\hline
\end{tabular}

Panel B: The presence of local directors on boards (by subsample)

\begin{tabular}{|c|c|c|c|c|c|c|c|c|}
\hline Firm size & $\begin{array}{c}\text { Small } \\
\text { (bottom } 75 \% \text { ) }\end{array}$ & $\begin{array}{c}\text { Large } \\
\text { (top } 25 \% \text { ) }\end{array}$ & $\Delta$ & & $\begin{array}{c}\text { Small } \\
\text { (bottom } 50 \% \text { ) }\end{array}$ & $\begin{array}{c}\text { Large } \\
\text { (top 50\%) }\end{array}$ & $\Delta$ & \\
\hline Local Independent Directors (\%) & 39.44 & 26.32 & 13.12 & & 42.09 & 30.2 & 11.85 & $* * *$ \\
\hline Local Gray Directors (\%) & 57.74 & 38.64 & 19.10 & *** & 65.13 & 41.9 & 23.21 & *** \\
\hline Local Outside Directors (\%) & 42.77 & 27.78 & 14.99 & *** & 46.59 & 31.9 & 14.71 & *** \\
\hline Indep. Dir. Distance to Exec. Job (Mean) & 4.70 & 5.48 & -0.78 & ${ }^{* * *}$ & 4.51 & 5.26 & -0.75 & *** \\
\hline Outside Dir. Distance to Exec. Job (Mean) & 4.52 & 5.45 & -0.94 & *** & 4.28 & 5.2 & -0.91 & ${ }^{* * *}$ \\
\hline Governance reforms & Before & After & $\Delta$ & & & & & \\
\hline Local Independent Directors (\%) & 34.91 & 30.80 & 4.11 & & & & & \\
\hline Local Gray Directors (\%) & 49.47 & 57.89 & -8.43 & $* *$ & & & & \\
\hline Local Outside Directors (\%) & 37.63 & 35.94 & 1.69 & & & & & \\
\hline Indep. Dir. Distance to Exec. Job (Mean) & 4.97 & 5.14 & -0.17 & & & & & \\
\hline Outside Dir. Distance to Exec. Job (Mean) & 4.85 & 4.90 & -0.05 & & & & & \\
\hline
\end{tabular}




\section{Table 2. Local director labor markets and board composition.}

We use the 1996-2006 sample of Compustat/CRSP firms that have RiskMetrics corporate governance measures, $13 \mathrm{f}$ institutional holdings, and Execucomp data available, excluding firms with total assets below twenty million, regulated financial and utility firms (SIC codes 6000-6999 and 4900-4999), and firms headquartered outside the continental US. The dependent variable is independent director representation on the board, Independent Directors (\%). Variable definitions are presented in Appendix A. Ordinary least squares regressions with three-digit SIC industry and year fixed effects. Robust t-statistics adjusted for clustering by firm are italicized. The symbols ${ }^{* * *},{ }^{* *}$ and ${ }^{*}$ denote significance at the $1 \%, 5 \%$ and $10 \%$ levels respectively.

\begin{tabular}{|c|c|c|c|c|c|}
\hline & I & II & & III & \\
\hline \multirow[t]{2}{*}{ Local director pool } & $0.740^{* * *}$ & 0.600 & ** & 0.646 & **** \\
\hline & 2.84 & 2.47 & & 2.78 & \\
\hline \multirow[t]{2}{*}{ Firm size } & & 1.189 & *** & 0.840 & **** \\
\hline & & 3.99 & & 2.90 & \\
\hline \multirow[t]{2}{*}{ Sales growth } & & -3.189 & *** & -2.707 & *** \\
\hline & & -3.49 & & -3.12 & \\
\hline \multirow[t]{2}{*}{$\mathrm{ROA}$} & & -4.426 & & -3.938 & \\
\hline & & -1.25 & & -1.15 & \\
\hline \multirow[t]{2}{*}{ Firm age } & & 2.085 & **** & 1.919 & *** \\
\hline & & 4.10 & & 3.88 & \\
\hline \multirow[t]{2}{*}{ Firm risk } & & 0.409 & & 0.160 & \\
\hline & & 1.31 & & 0.54 & \\
\hline \multirow[t]{2}{*}{ Institutional ownership } & & 0.190 & *** & 0.152 & *** \\
\hline & & 8.49 & & 6.96 & \\
\hline \multirow[t]{2}{*}{ G Index } & & 0.833 & *** & 0.710 & *** \\
\hline & & 5.77 & & 5.06 & \\
\hline \multirow[t]{2}{*}{ Tangible asset intensity } & & & & 4.378 & \\
\hline & & & & 1.60 & \\
\hline \multirow[t]{2}{*}{ R\&D intensity indicator } & & & & 4.412 & *** \\
\hline & & & & 3.99 & \\
\hline \multirow[t]{2}{*}{ CEO ownership } & & & & -0.354 & *** \\
\hline & & & & -5.59 & \\
\hline \multirow[t]{2}{*}{ CEO age } & & & & -4.576 & *** \\
\hline & & & & -5.27 & \\
\hline \multirow[t]{2}{*}{ CEO tenure } & & & & -0.264 & \\
\hline & & & & -0.85 & \\
\hline Obs. & 9693 & 9693 & & 9693 & \\
\hline $\mathrm{R}^{2}$ & 0.24 & 0.30 & & 0.33 & \\
\hline Adj. $\mathrm{R}^{2}$ & 0.22 & 0.29 & & 0.31 & \\
\hline
\end{tabular}




\section{Table 3. Local director labor markets and board independence: Subsample analysis.}

We use the 1996-2006 sample of Compustat/CRSP firms that have RiskMetrics corporate governance measures, 13f institutional holdings, and Execucomp data available, excluding firms with total assets below twenty million, regulated financial and utility firms (SIC codes 6000-6999 and 4900-4999), and firms headquartered outside the continental US. The dependent variable is independent director representation on the board, Independent Directors (\%). Variable definitions are presented in Appendix A. Ordinary least squares regressions by subsample. Control variables from Table 2, column III are included but not shown for brevity. Subsamples in Panel A are identified based on Firm size (total assets). In Panel B, observations before governance reforms include firm-years 19992002, whereas observations after governance reforms include firm-years 2003-2006, for firms that failed to meet one of the following governance requirements by 2001 - majority of independent directors on the board, independent directors on nominating/governance and compensation committees and three independent directors on the audit committee. Three-digit SIC industry and year fixed effects are included. Robust t-statistics adjusted for clustering by firm are italicized. The symbols ${ }^{* * *},{ }^{* *}$ and ${ }^{*}$ denote significance at the $1 \%$, $5 \%$ and $10 \%$ levels respectively.

Panel A: Firm visibility

\begin{tabular}{lcccc} 
& $\begin{array}{c}\text { Small } \\
\text { (bottom 75\%) }\end{array}$ & $\begin{array}{c}\text { Large } \\
\text { (top 25\%) }\end{array}$ & $\begin{array}{c}\text { Small } \\
\text { (bottom 50\%) }\end{array}$ & $\begin{array}{c}\text { Large } \\
\text { (top 50\%) }\end{array}$ \\
\cline { 2 - 5 } Local director pool & $0.590^{* *}$ & 0.374 & $0.686^{* *}$ & 0.431 \\
2.36 & 0.70 & 2.30 & 1.24
\end{tabular}

The symbols ${ }^{* * * * *},{ }^{* *}$ and ${ }^{*}$ denote significance at the $1 \%, 5 \%$ and $10 \%$ levels respectively.

Panel B: Governance reforms

\begin{tabular}{ccc}
\hline & $\begin{array}{c}\text { Before reforms } \\
\text { All firms }\end{array}$ & $\begin{array}{c}\text { After reforms } \\
\text { All firms }\end{array}$ \\
\hline Local director pool & $0.808^{* * *}$ & $0.673^{*}$ \\
& $2.73^{*}$ & $1.87^{*}$ \\
\hline
\end{tabular}




\section{Table 4. Local director labor markets and board composition: robustness checks}

We use the 1996-2006 sample of Compustat/CRSP firms that have RiskMetrics corporate governance measures, 13f institutional holdings, and Execucomp data available, excluding firms with total assets below twenty million, regulated financial and utility firms (SIC codes 6000-6999 and 4900-4999), and firms headquartered outside the continental US. The dependent variable is independent director representation on the board, Independent Directors (\%). Variable definitions are presented in Appendix A. Ordinary least squares regressions with three-digit SIC industry and year fixed effects. Robust t-statistics adjusted for clustering by firm are italicized.

Panel A uses other Local director pool definitions: same county (column I); hundred-mile radius (column II); including Canadian firms (column III); excluding firms smaller than our firm (column IV); excluding small firms (column V); including all financial and nonfinancial firms (column VI). Panel B adds controls for industry clusters (column I); population density, upper-income household density, retirement income household density, college graduates, Census region dummies, and unemployment (\%) (column II); mean of board independence in the state (column III); business and regional diversification (column IV); classified board and dual class shares dummies (column V); NYSE listing and big- and medium-sized city dummies (column VI).

Panel C uses alternative definitions and sample criteria: logit transformation of board independence, $\ln [\mathrm{y} /(1-\mathrm{y})]$ (column I); excluding firms headquartered in the ten largest metropolitan areas (column II); excluding firms headquartered in CA, IL, MA, and NY (column III); excluding hightech and automotive firms (column IV); excluding firms that entered the sample during our sample period (column V); excluding observations with acquisition spending in excess of five percent percent of total assets (column VI). The sample is next matched to Compact Disclosure (CD) historical headquarters location data for 1996-2004 (last reliable reporting year). Firms whose historical headquarters locations from CD are more than sixty (twenty) miles away from their Compustat location are excluded in columns VII and IX (VIII and X); columns IX-X exclude firms that could not be matched to $\mathrm{CD}$ data due to differences in sample coverage. The symbols ${ }^{* * *},{ }^{* *}$ and ${ }^{*}$ denote significance at the $1 \%, 5 \%$ and $10 \%$ levels respectively.

\begin{tabular}{|c|c|c|c|c|c|c|c|c|c|c|c|c|}
\hline \multirow[b]{2}{*}{ Local director pool (same county) } & \multicolumn{2}{|l|}{ I } & \multicolumn{2}{|l|}{ II } & \multicolumn{2}{|l|}{ III } & \multicolumn{2}{|l|}{ IV } & \multicolumn{2}{|l|}{$\mathrm{V}$} & \multicolumn{2}{|l|}{ VI } \\
\hline & 0.528 & & & & & & & & & & & \\
\hline Local director pool (100mi) & 2.17 & & $\begin{array}{r}0.571 \\
2.43\end{array}$ & *** & & & & & & & & \\
\hline Local director pool (incl. Canada) & & & & & $\begin{array}{r}0.648 \\
2.79\end{array}$ & *** & & & & & & \\
\hline Local director pool (similar or larger) & & & & & & & $\begin{array}{r}0.740 \\
2.85\end{array}$ & *** & & & & \\
\hline Local director pool (excl. small) & & & & & & & & & $\begin{array}{r}0.654 \\
2.67\end{array}$ & *** & & \\
\hline Local director pool (all firms) & & & & & & & & & & & $\begin{array}{r}0.581 \\
2.01 \\
\end{array}$ & ${ }^{* *}$ \\
\hline Firm size & 0.875 & ${ }^{* * *}$ & 0.861 & *** & 0.839 & *** & 1.024 & *** & 0.841 & "*** & 0.861 & *** \\
\hline Sales growth & $\begin{array}{r}3.04 \\
-2.775 \\
-3.20\end{array}$ & $* * *$ & $\begin{array}{r}2.98 \\
-2.711 \\
-3.12\end{array}$ & *** & $\begin{array}{r}2.90 \\
-2.705 \\
-3.12\end{array}$ & *** & $\begin{array}{r}3.53 \\
-2.686 \\
-3.10\end{array}$ & *** & $\begin{array}{r}2.91 \\
-2.701 \\
-3.11\end{array}$ & $* * *$ & $\begin{array}{r}2.98 \\
-2.707 \\
-3.11\end{array}$ & *** \\
\hline ROA & -3.856 & & -3.961 & & -3.939 & & -3.898 & & -3.935 & & -3.852 & \\
\hline & -1.12 & & -1.15 & & $\begin{array}{l}-1.15 \\
1019\end{array}$ & & -1.14 & & -1.15 & & -1.12 & \\
\hline Firm age & $\begin{array}{r}1.935 \\
3.91\end{array}$ & **** & $\begin{array}{r}1.916 \\
3.86\end{array}$ & *** & $\begin{array}{r}1.919 \\
3.88\end{array}$ & *** & $\begin{array}{r}1.903 \\
3.85\end{array}$ & *** & $\begin{array}{r}1.921 \\
3.88\end{array}$ & **** & $\begin{array}{r}1.908 \\
3.85\end{array}$ & ${ }^{* * * *}$ \\
\hline Firm risk & 0.183 & & 0.169 & & 0.160 & & 0.153 & & 0.170 & & 0.190 & \\
\hline Institutional ownership & $\begin{array}{r}0.61 \\
0.153 \\
6.99\end{array}$ & $* * *$ & $\begin{array}{r}0.57 \\
0.152 \\
6.98\end{array}$ & *** & $\begin{array}{r}0.53 \\
0.152 \\
6.96\end{array}$ & *** & $\begin{array}{r}0.51 \\
0.153 \\
7.02\end{array}$ & *** & $\begin{array}{r}0.57 \\
0.152 \\
6.97\end{array}$ & $* * *$ & $\begin{array}{r}0.63 \\
0.152 \\
6.95\end{array}$ & *** \\
\hline Tangible asset intensity & $\begin{array}{r}4.340 \\
1.58\end{array}$ & & $\begin{array}{r}4.247 \\
1.55\end{array}$ & & $\begin{array}{r}4.381 \\
1.60\end{array}$ & & $\begin{array}{r}4.389 \\
1.60\end{array}$ & & $\begin{array}{r}4.344 \\
1.58\end{array}$ & & $\begin{array}{r}4.109 \\
1.50\end{array}$ & \\
\hline $\mathrm{R} \& \mathrm{D}$ intensity indicator & $\begin{array}{r}4.490 \\
4.04\end{array}$ & *** & $\begin{array}{r}4.377 \\
3.96\end{array}$ & $* * *$ & $\begin{array}{r}4.414 \\
3.99\end{array}$ & *** & $\begin{array}{r}4.371 \\
3.96\end{array}$ & *** & $\begin{array}{r}4.394 \\
3.98\end{array}$ & *** & $\begin{array}{r}4.380 \\
3.95\end{array}$ & *** \\
\hline G Index & $\begin{array}{r}0.694 \\
4.94\end{array}$ & *** & $\begin{array}{r}0.701 \\
5.01\end{array}$ & *** & $\begin{array}{r}0.710 \\
5.06\end{array}$ & *** & $\begin{array}{r}0.710 \\
5.05\end{array}$ & *** & $\begin{array}{r}0.706 \\
5.03\end{array}$ & *** & $\begin{array}{r}0.703 \\
5.01\end{array}$ & ${ }^{* * *}$ \\
\hline CEO ownership & $\begin{array}{r}-0.351 \\
-5.55\end{array}$ & $* * *$ & $\begin{array}{r}-0.354 \\
-5.58\end{array}$ & $* * *$ & $\begin{array}{r}-0.354 \\
-5.59\end{array}$ & $* * *$ & $\begin{array}{r}-0.354 \\
-5.58\end{array}$ & $* * *$ & $\begin{array}{r}-0.355 \\
-5.59\end{array}$ & $* * *$ & $\begin{array}{r}-0.357 \\
-5.63\end{array}$ & $* * *$ \\
\hline CEO age & $\begin{array}{r}-4.560 \\
-5.25\end{array}$ & *** & $\begin{array}{r}-4.573 \\
-5.25\end{array}$ & $* * *$ & $\begin{array}{r}-4.574 \\
-5.26\end{array}$ & *** & $\begin{array}{r}-4.569 \\
-5.26\end{array}$ & $* * *$ & $\begin{array}{r}-4.557 \\
-5.24\end{array}$ & $* * *$ & $\begin{array}{r}-4.553 \\
-5.23\end{array}$ & ${ }^{* * *}$ \\
\hline CEO tenure & $\begin{array}{r}-0.274 \\
-0.88 \\
\end{array}$ & & $\begin{array}{r}-0.266 \\
-0.86 \\
\end{array}$ & & $\begin{array}{r}-0.264 \\
-0.85 \\
\end{array}$ & & $\begin{array}{r}-0.263 \\
-0.85 \\
\end{array}$ & & $\begin{array}{r}-0.267 \\
-0.86 \\
\end{array}$ & & $\begin{array}{r}-0.265 \\
-0.85 \\
\end{array}$ & \\
\hline Obs. & 9693 & & 9693 & & 9693 & & 9693 & & 9693 & & 9693 & \\
\hline $\mathrm{R}^{2}$ & 0.33 & & 0.33 & & 0.33 & & 0.33 & & 0.33 & & 0.33 & \\
\hline Adj. $R^{2}$ & 0.31 & & 0.31 & & 0.31 & & 0.31 & & 0.31 & & 0.31 & \\
\hline
\end{tabular}

The symbols ${ }^{* * *},{ }^{* *}$ and ${ }^{*}$ denote significance at the $1 \%, 5 \%$ and $10 \%$ levels respectively. 
Panel B: Alternative explanations and additional control variables

\begin{tabular}{|c|c|c|c|c|c|c|c|c|c|c|c|c|}
\hline \multirow{3}{*}{ Local director pool } & I & & II & & III & & IV & & V & & VI & \\
\hline & 0.626 & & 1.125 & & 0.449 & & 0.620 & & 0.554 & & 1.127 & \\
\hline & 2.30 & & 3.09 & & 2.02 & & 2.60 & & 2.39 & & 3.44 & \\
\hline \multirow[t]{2}{*}{ Firm size } & 0.837 & & 0.894 & & 0.953 & & 0.625 & ** & 0.915 & & 0.780 & \\
\hline & 2.88 & & 3.14 & & 3.35 & & 2.02 & & 3.20 & & 2.60 & \\
\hline \multirow[t]{2}{*}{ Sales growth } & -2.706 & *** & -2.790 & *** & -2.635 & *** & -2.190 & *** & -3.184 & $* * *$ & -2.687 & $* * *$ \\
\hline & -3.12 & & -3.20 & & -3.04 & & -2.60 & & -3.66 & & -3.13 & \\
\hline \multirow[t]{2}{*}{ ROA } & -3.941 & & -4.461 & & -3.602 & & -3.417 & & -4.648 & & -4.757 & \\
\hline & -1.15 & & -1.29 & & -1.05 & & -0.98 & & -1.35 & & -1.37 & \\
\hline \multirow[t]{2}{*}{ Firm age } & 1.923 & *** & 2.044 & *** & 1.865 & *** & 1.891 & $* * *$ & 2.185 & $* * *$ & 1.852 & $* * *$ \\
\hline & 3.88 & & 4.14 & & 3.78 & & 3.63 & & 4.50 & & 3.74 & \\
\hline \multirow[t]{2}{*}{ Firm risk } & 0.157 & & 0.103 & & 0.105 & & 0.251 & & 0.021 & & 0.308 & \\
\hline & 0.52 & & 0.35 & & 0.36 & & 0.82 & & 0.07 & & 1.03 & \\
\hline \multirow[t]{2}{*}{ Institutional ownership } & 0.152 & ${ }^{* * *}$ & 0.152 & ${ }^{* * *}$ & 0.149 & ${ }^{* * *}$ & 0.155 & *** & 0.165 & ${ }^{* * * *}$ & 0.156 & ${ }^{* * *}$ \\
\hline & 6.95 & & 7.03 & & 6.96 & & 6.87 & & 7.73 & & 7.20 & \\
\hline \multirow[t]{2}{*}{ Tangible asset intensity } & 4.379 & & 4.493 & * & 3.151 & & 5.422 & * & 4.366 & & 4.044 & \\
\hline & 1.60 & & 1.65 & & 1.18 & & 1.91 & & 1.61 & & 1.47 & \\
\hline \multirow[t]{2}{*}{ R\&D intensity indicator } & 4.394 & *** & 4.222 & *** & 4.356 & *** & 4.096 & *** & 4.632 & *** & 4.478 & *** \\
\hline & 3.98 & & 3.94 & & 4.12 & & 3.56 & & 4.22 & & 4.07 & \\
\hline \multirow[t]{2}{*}{ G Index } & 0.712 & *** & 0.687 & *** & 0.608 & *** & 0.761 & *** & & & 0.676 & *** \\
\hline & 5.06 & & 4.88 & & 4.33 & & 5.16 & & & & 4.81 & \\
\hline \multirow[t]{2}{*}{ CEO ownership } & -0.354 & *** & -0.343 & *** & -0.345 & *** & -0.329 & *** & -0.367 & *** & -0.345 & *** \\
\hline & -5.59 & & -5.45 & & -5.43 & & -5.31 & & -5.91 & & -5.46 & \\
\hline \multirow[t]{2}{*}{ CEO age } & -4.576 & *** & -4.324 & *** & -4.309 & *** & -4.763 & *** & -4.423 & $* * *$ & -4.628 & $* * *$ \\
\hline & -5.26 & & -5.05 & & -5.02 & & -5.40 & & -5.19 & & -5.34 & \\
\hline \multirow[t]{2}{*}{ CEO tenure } & -0.265 & & -0.303 & & -0.308 & & -0.184 & & -0.155 & & -0.189 & \\
\hline & -0.85 & & -0.98 & & -1.01 & & -0.57 & & -0.50 & & -0.62 & \\
\hline Industry cluster & $\begin{array}{r}0.079 \\
0.14\end{array}$ & & & & & & & & & & & \\
\hline Population density & & & $\begin{array}{r}1.902 \\
0.38\end{array}$ & & & & & & & & & \\
\hline Upper-income density & & & -4.615 & & & & & & & & & \\
\hline & & & -1.08 & & & & & & & & & \\
\hline Retirement income density & & & 3.103 & & & & & & & & & \\
\hline & & & 1.30 & & & & & & & & & \\
\hline College graduates $(\%)$ & & & 0.102 & & & & & & & & & \\
\hline & & & 0.49 & & & & & & & & & \\
\hline Unemployment (\%) & & & -0.650 & *** & & & & & & & & \\
\hline & & & -2.93 & & & & & & & & & \\
\hline Mean (state) & & & & & 0.710 & *** & & & & & & \\
\hline & & & & & 8.76 & & & & & & & \\
\hline Business segments & & & & & & & 0.577 & & & & & \\
\hline & & & & & & & 1.04 & & & & & \\
\hline Foreign segment & & & & & & & 0.993 & & & & & \\
\hline & & & & & & & 1.28 & & & & & \\
\hline Classified board & & & & & & & & & 1.040 & & & \\
\hline & & & & & & & & & 1.47 & & & \\
\hline Dual class firm & & & & & & & & & -8.341 & *** & & \\
\hline & & & & & & & & & -6.48 & & & \\
\hline NYSE listing & & & & & & & & & & & 1.570 & * \\
\hline & & & & & & & & & & & 1.66 & \\
\hline Big city & & & & & & & & & & & -2.450 & * \\
\hline & & & & & & & & & & & -1.65 & \\
\hline Medium-sized city & & & & & & & & & & & 0.141 & \\
\hline & & & & & & & & & & & 0.11 & \\
\hline Obs. & 9693 & & 9693 & & 9693 & & 8650 & & 9693 & & 9693 & \\
\hline $\mathrm{R}^{2}$ & 0.33 & & 0.34 & & 0.35 & & 0.34 & & 0.34 & & 0.33 & \\
\hline Adj. $R^{2}$ & 0.31 & & 0.32 & & 0.33 & & 0.32 & & 0.32 & & 0.32 & \\
\hline
\end{tabular}


Panel C: Alternative sample selection criteria and variable definitions

\begin{tabular}{|c|c|c|c|c|c|c|c|c|c|c|c|c|c|c|c|c|c|c|c|c|}
\hline \multirow{3}{*}{ Local director pool } & \multicolumn{2}{|l|}{ I } & \multicolumn{2}{|l|}{ II } & \multicolumn{2}{|l|}{ III } & \multicolumn{2}{|l|}{ IV } & \multicolumn{2}{|l|}{$\mathrm{V}$} & \multicolumn{2}{|l|}{ VI } & \multicolumn{2}{|l|}{ VII } & \multicolumn{2}{|l|}{ VIII } & \multicolumn{2}{|l|}{ IX } & \multicolumn{2}{|l|}{$\mathrm{X}$} \\
\hline & 0.029 & *** & 1.499 & *** & 1.138 & *** & 0.582 & $* *$ & 0.726 & *** & 0.610 & *** & 0.723 & *** & 0.760 & *** & 0.522 & * & 0.617 & ** \\
\hline & 2.59 & & 3.87 & & 3.80 & & 2.14 & & 2.89 & & 2.58 & & 2.82 & & 2.98 & & 1.69 & & 2.00 & \\
\hline \multirow[t]{2}{*}{ Firm size } & 0.047 & $* * *$ & 0.478 & & 0.833 & $* *$ & 0.770 & $* *$ & 0.570 & * & 0.903 & ${ }^{* * *}$ & 0.868 & ${ }^{* * *}$ & 0.872 & $* * *$ & 0.240 & & 0.204 & \\
\hline & 3.31 & & 1.14 & & 2.39 & & 2.15 & & 1.78 & & 3.00 & & 2.66 & & 2.66 & & 0.58 & & 0.49 & \\
\hline \multirow[t]{2}{*}{ Sales growth } & -0.130 & $* * *$ & -2.975 & $* *$ & -4.167 & $* * *$ & -4.510 & $* * *$ & -2.510 & $* * *$ & -2.083 & $* *$ & -2.103 & $* *$ & -2.231 & $* *$ & -1.700 & & -1.783 & \\
\hline & -3.12 & & -2.01 & & -3.37 & & -3.88 & & -2.89 & & -2.13 & & -2.12 & & -2.13 & & -1.63 & & -1.60 & \\
\hline \multirow[t]{2}{*}{ ROA } & -0.193 & & -3.869 & & -5.237 & & 0.562 & & -4.676 & & -3.515 & & -3.819 & & -3.073 & & -5.867 & & -5.304 & \\
\hline & -1.18 & & -0.68 & & -1.17 & & 0.14 & & -1.29 & & -0.99 & & -0.98 & & -0.77 & & -1.28 & & -1.12 & \\
\hline \multirow[t]{2}{*}{ Firm age } & 0.095 & $* * *$ & 1.797 & $* *$ & 1.749 & *** & 2.189 & $* * *$ & 3.526 & $* * *$ & 1.654 & $* * *$ & 2.144 & $* * *$ & 2.239 & $* * *$ & 1.737 & $* *$ & 1.873 & *** \\
\hline & 3.82 & & 2.43 & & 3.00 & & 3.96 & & 5.07 & & 3.24 & & 3.97 & & 4.11 & & 2.56 & & 2.72 & \\
\hline \multirow[t]{2}{*}{ Firm risk } & 0.010 & & -0.339 & & 0.142 & & 0.193 & & 0.249 & & 0.072 & & 0.340 & & 0.379 & & 0.521 & & 0.535 & \\
\hline & 0.66 & & -0.75 & & 0.38 & & 0.53 & & 0.75 & & 0.24 & & 1.02 & & 1.13 & & 1.35 & & 1.36 & \\
\hline \multirow[t]{2}{*}{ Institutional ownership } & 0.007 & $* * *$ & 0.180 & $* * *$ & 0.176 & $* * *$ & 0.164 & $* * *$ & 0.162 & $* * *$ & 0.146 & $* * *$ & 0.150 & $* * *$ & 0.155 & $* * *$ & 0.148 & $* * *$ & 0.153 & $* * *$ \\
\hline & 6.83 & & 6.25 & & 6.81 & & 6.51 & & 6.92 & & 6.56 & & 6.19 & & 6.37 & & 5.06 & & 5.18 & \\
\hline \multirow[t]{2}{*}{ Tangible asset intensity } & 0.203 & & 2.318 & & 2.895 & & 0.736 & ${ }^{* * *}$ & 0.592 & ${ }^{* * *}$ & 3.533 & & 6.460 & $* *$ & 6.312 & $* *$ & 5.902 & $*$ & 5.754 & \\
\hline & 1.52 & & 0.61 & & 0.92 & & 4.62 & & 3.90 & & 1.26 & & 2.12 & & 2.07 & & 1.65 & & 1.59 & \\
\hline \multirow[t]{2}{*}{$\mathrm{R} \& \mathrm{D}$ intensity indicator } & 0.214 & $* * *$ & 4.463 & $* * *$ & 4.622 & $* * *$ & 2.162 & & 5.705 & * & 4.441 & *** & 4.074 & $* * *$ & 4.131 & $* * *$ & 6.443 & $* * *$ & 6.824 & *** \\
\hline & 4.00 & & 2.80 & & 3.57 & & 0.71 & & 1.95 & & 3.93 & & 3.21 & & 3.21 & & 4.72 & & 4.87 & \\
\hline \multirow[t]{2}{*}{ G Index } & 0.035 & $* * *$ & 0.968 & $* * *$ & 0.997 & $* * *$ & 3.960 & $* * *$ & 3.716 & $* * *$ & 0.694 & $* * *$ & 0.845 & $* * *$ & 0.852 & $* * *$ & 0.727 & $* * *$ & 0.749 & $* * *$ \\
\hline & 5.07 & & 4.63 & & 5.93 & & 3.29 & & 3.20 & & 4.74 & & 5.47 & & 5.48 & & 3.67 & & 3.73 & \\
\hline \multirow[t]{2}{*}{ CEO ownership } & -0.017 & $* * *$ & -0.320 & $* * *$ & -0.278 & $* * *$ & -0.342 & ${ }^{* * *}$ & -0.385 & ${ }^{* * *}$ & -0.361 & ${ }^{* * *}$ & -0.379 & $* * *$ & -0.374 & ${ }^{* * *}$ & -0.448 & $* * *$ & -0.438 & *** \\
\hline & -5.70 & & -3.19 & & -3.60 & & -4.71 & & -5.99 & & -5.50 & & -5.64 & & -5.56 & & -5.54 & & -5.42 & \\
\hline \multirow[t]{2}{*}{ CEO age } & -0.222 & $* * *$ & -3.875 & $* * *$ & -3.245 & $* * *$ & -4.527 & $* * *$ & -4.673 & $* * *$ & -4.260 & $* * *$ & -5.248 & $* * *$ & -5.238 & $* * *$ & -4.037 & $* * *$ & -4.056 & $* * *$ \\
\hline & -5.36 & & -3.21 & & -3.09 & & -4.76 & & -5.13 & & -4.65 & & -5.56 & & -5.54 & & -3.35 & & -3.35 & \\
\hline \multirow[t]{2}{*}{ CEO tenure } & -0.010 & & -0.275 & & -0.308 & & -0.136 & & -0.259 & & -0.350 & & -0.341 & & -0.277 & & 0.255 & & 0.338 & \\
\hline & -0.70 & & -0.64 & & -0.82 & & -0.38 & & -0.80 & & -1.07 & & -0.98 & & -0.80 & & 0.58 & & 0.77 & \\
\hline Obs. & 9693 & & 4672 & & 6437 & & 7424 & & 8642 & & 8002 & & 7673 & & 7580 & & 4717 & & 4624 & \\
\hline $\mathrm{R}^{2}$ & 0.33 & & 0.43 & & 0.39 & & 0.36 & & 0.35 & & 0.33 & & 0.34 & & 0.34 & & 0.37 & & 0.37 & \\
\hline Adj. $\mathrm{R}^{2}$ & 0.31 & & 0.41 & & 0.37 & & 0.34 & & 0.33 & & 0.31 & & 0.32 & & 0.32 & & 0.34 & & 0.34 & \\
\hline
\end{tabular}




\section{Table 5. Local director labor markets and other board characteristics.}

We use the 1996-2006 sample of Compustat/CRSP firms that have RiskMetrics corporate governance measures, 13f institutional holdings, and Execucomp data available, excluding firms with total assets below twenty million, regulated financial and utility firms (SIC codes 6000-6999 and 4900-4999), and firms headquartered outside the continental US. Ordinary least squares regressions with three-digit SIC industry and year fixed effects. Robust t-statistics adjusted for clustering by firm are italicized.

Panel A examines other board characteristics. Panel B examines the proportion of executive experts among independent directors (columns I-II) and outside directors (columns III-V); column V uses BoardEx data on director characteristics; columns VI-IX examine representation of local executives among independent, outside, and gray directors with executive positions. Panel $\mathrm{C}$ examines specialized board expertise (technology, legal and financial). Columns I-IV use the main sample. Columns V-VI use BoardEx data for all firms, including regulated firms (SIC 6000-6999, 4900-4999). Columns I and III use independent directors. Columns II and IV-VI use outside directors. The symbols ${ }^{* * *},{ }^{* *}$ and ${ }^{*}$ denote significance at the $1 \%, 5 \%$ and $10 \%$ levels respectively.

Panel A: Local director labor markets and other board characteristics

\begin{tabular}{|c|c|c|c|c|c|c|}
\hline \multirow{3}{*}{ Local director pool } & \multirow{2}{*}{\multicolumn{2}{|c|}{$\begin{array}{c}\text { Gray directors }(\%) \\
\text { I }\end{array}$}} & \multirow{2}{*}{\multicolumn{2}{|c|}{$\begin{array}{c}\text { Inside directors }(\%) \\
\text { II } \\
\end{array}$}} & \multirow{2}{*}{\multicolumn{2}{|c|}{$\begin{array}{c}\text { Board size } \\
\text { III }\end{array}$}} \\
\hline & & & & & & \\
\hline & -0.689 & ** & -0.426 & * & -0.002 & \\
\hline & -2.50 & & -1.75 & & -0.47 & \\
\hline \multirow[t]{2}{*}{ Firm size } & -0.053 & & -0.726 & **** & 0.076 & ${ }^{* * * *}$ \\
\hline & -0.20 & & -3.79 & & 17.58 & \\
\hline \multirow[t]{2}{*}{ Sales growth } & 0.915 & & 1.788 & $* * *$ & -0.022 & ** \\
\hline & 1.40 & & 4.04 & & -2.45 & \\
\hline \multirow[t]{2}{*}{ ROA } & 0.105 & & 4.857 & $* *$ & -0.006 & \\
\hline & 0.04 & & 2.47 & & -0.14 & \\
\hline \multirow[t]{2}{*}{ Firm age } & -1.124 & ${ }^{* * *}$ & -0.714 & $* *$ & 0.047 & *** \\
\hline & -2.65 & & -2.46 & & 6.89 & \\
\hline \multirow[t]{2}{*}{ Firm risk } & -0.075 & & -0.228 & & -0.024 & *** \\
\hline & -0.30 & & -1.21 & & -5.98 & \\
\hline \multirow[t]{2}{*}{ Institutional ownership } & -0.106 & *** & -0.047 & $* * *$ & -0.002 & ${ }^{* * *}$ \\
\hline & -5.60 & & -3.33 & & -7.20 & \\
\hline \multirow[t]{2}{*}{ G Index } & -0.147 & & -0.527 & *** & 0.009 & *** \\
\hline & -1.22 & & -5.98 & & 5.01 & \\
\hline \multirow[t]{2}{*}{ Tangible asset intensity } & -1.279 & & -2.913 & & 0.049 & \\
\hline & -0.58 & & -1.54 & & 1.22 & \\
\hline \multirow[t]{2}{*}{ R\&D intensity indicator } & -3.506 & $* * *$ & -0.986 & & 0.017 & \\
\hline & -3.75 & & -1.25 & & 1.03 & \\
\hline \multirow[t]{2}{*}{ CEO ownership } & 0.029 & & 0.325 & $* * *$ & -0.004 & *** \\
\hline & 0.54 & & 6.47 & & -4.21 & \\
\hline \multirow[t]{2}{*}{ CEO age } & 0.777 & & 3.647 & $* * *$ & 0.028 & $* *$ \\
\hline & 1.01 & & 5.12 & & 1.97 & \\
\hline \multirow[t]{2}{*}{ CEO tenure } & -0.356 & & 0.512 & $* *$ & -0.006 & \\
\hline & -1.39 & & 2.36 & & -1.32 & \\
\hline \multirow[t]{2}{*}{ NYSE listing } & 0.276 & & -1.941 & $* * *$ & 0.030 & $* *$ \\
\hline & 0.35 & & -3.19 & & 2.20 & \\
\hline \multirow[t]{2}{*}{ Big city } & 2.273 & $*$ & 0.069 & & -0.009 & \\
\hline & 1.87 & & 0.06 & & -0.43 & \\
\hline \multirow[t]{2}{*}{ Medium-sized city } & 1.340 & & -1.505 & $*$ & 0.014 & \\
\hline & 1.31 & & -1.71 & & 0.84 & \\
\hline Obs. & 9693 & & 9693 & & 9693 & \\
\hline $\mathrm{R}^{2}$ & 0.18 & & 0.33 & & 0.49 & \\
\hline Adj. $\mathrm{R}^{2}$ & 0.16 & & 0.31 & & 0.48 & \\
\hline
\end{tabular}


Panel B: Local director labor markets, executive expertise and appointments of local directors

\begin{tabular}{|c|c|c|c|c|c|c|c|c|c|c|c|c|c|c|c|c|c|c|}
\hline \multirow{4}{*}{ Local director pool } & \multicolumn{4}{|c|}{ Executive Expertise (\%) } & \multicolumn{4}{|c|}{ Executive Expertise (\%) } & \multicolumn{2}{|c|}{$\begin{array}{l}\text { Executive } \\
\text { Expertise (\%) }\end{array}$} & \multicolumn{2}{|c|}{$\begin{array}{c}\text { Local } \\
\text { independent } \\
\text { directors }(\%) \\
\end{array}$} & \multicolumn{2}{|c|}{$\begin{array}{l}\text { Local outside } \\
\text { directors (\%) }\end{array}$} & \multicolumn{2}{|c|}{$\begin{array}{c}\text { Local gray } \\
\text { directors (\%) }\end{array}$} & \multicolumn{2}{|c|}{$\begin{array}{c}\text { Independent } \\
\text { director distance } \\
\text { to exec. job }\end{array}$} \\
\hline & \multicolumn{2}{|l|}{$\mathrm{I}$} & \multicolumn{2}{|l|}{ II } & \multicolumn{2}{|l|}{ III } & \multicolumn{2}{|l|}{ IV } & \multicolumn{2}{|l|}{$\mathrm{V}$} & \multicolumn{2}{|l|}{ VI } & \multicolumn{2}{|l|}{ VII } & \multicolumn{2}{|l|}{ VIII } & \multicolumn{2}{|l|}{ IX } \\
\hline & 0.651 & $F^{* * *}$ & & & 0.512 & * & & & 0.743 & * & 7.987 & **** & 7.277 & ${ }^{* * * *}$ & 7.007 & ** & -0.259 & \\
\hline & 2.23 & & & & 1.93 & & & & 1.89 & & 7.95 & & 7.74 & & 2.67 & & -4.91 & \\
\hline Local director pool & & & 0.774 & $* *$ & & & 0.635 & $* *$ & & & & & & & & & & \\
\hline (similar or larger) & & & 2.34 & & & & 2.14 & & & & & & & & & & & \\
\hline Firm size & 0.225 & & 0.422 & & 0.598 & * & 0.756 & ** & 1.736 & *** & -4.352 & $* * *$ & -5.022 & $* * *$ & -9.643 & $* * *$ & 0.255 & $* * *$ \\
\hline & 0.64 & & 1.20 & & 1.84 & & 2.33 & & 4.70 & & -3.46 & & -4.21 & & -3.02 & & 4.07 & \\
\hline Sales growth & 1.326 & & 1.347 & & 1.614 & $*$ & 1.633 & $*$ & -1.346 & & 0.006 & & -1.869 & & -6.211 & & -0.032 & \\
\hline & 1.33 & & 1.35 & & 1.75 & & 1.77 & & -1.13 & & 0.00 & & -0.56 & & -0.93 & & -0.14 & \\
\hline ROA & 6.347 & & 6.379 & & 3.296 & & 3.325 & & -0.354 & & 13.575 & & 16.938 & & 28.906 & & -1.097 & \\
\hline & 1.42 & & 1.42 & & 0.81 & & 0.81 & & -0.08 & & 0.80 & & 1.09 & & 0.69 & & -1.28 & \\
\hline Firm age & 1.182 & ${ }^{*}$ & 1.163 & * & 0.136 & & 0.119 & & -1.416 & ** & -1.913 & & -2.273 & & 5.066 & & 0.064 & \\
\hline & 1.93 & & 1.90 & & 0.25 & & 0.22 & & -2.13 & & -1.02 & & -1.21 & & 1.12 & & 0.68 & \\
\hline Firm risk & 0.443 & & 0.429 & & 0.677 & $*$ & 0.662 & $*$ & 0.676 & ** & 1.741 & & 1.311 & & -3.038 & & -0.124 & \\
\hline & 1.11 & & 1.07 & & 1.90 & & 1.85 & & 2.21 & & 1.34 & & 1.02 & & -0.81 & & -1.64 & \\
\hline Institutional ownership & 0.030 & & 0.031 & & 0.019 & & 0.020 & & & & -0.135 & & -0.228 & ${ }^{* *}$ & -0.446 & $*$ & 0.006 & \\
\hline & 1.09 & & 1.13 & & 0.78 & & 0.81 & & & & -1.48 & & -2.40 & & -1.86 & & 1.40 & \\
\hline G Index & 0.120 & & 0.121 & & 0.233 & & 0.234 & & & & 1.335 & ** & 1.173 & ** & -0.946 & & -0.054 & * \\
\hline & 0.65 & & 0.65 & & 1.41 & & 1.42 & & & & 2.36 & & 2.11 & & -0.73 & & -1.85 & \\
\hline Tangible asset intensity & 0.373 & & 0.415 & & 2.613 & & 2.675 & & -6.173 & & 0.352 & & 1.517 & & -4.799 & & 0.180 & \\
\hline & 0.11 & & 0.12 & & 0.83 & & 0.85 & & -1.54 & & 0.03 & & 0.13 & & -0.18 & & 0.29 & \\
\hline $\mathrm{R} \& \mathrm{D}$ intensity indicator & 1.477 & & 1.442 & & 1.988 & $*$ & 1.959 & & 3.342 & ** & 7.802 & * & 10.936 & ${ }^{* * *}$ & 22.976 & ** & -0.273 & \\
\hline & 1.08 & & 1.05 & & 1.67 & & 1.64 & & 2.17 & & 1.69 & & 2.59 & & 2.19 & & -1.19 & \\
\hline CEO ownership & -0.135 & & -0.134 & & -0.099 & & -0.099 & & -0.344 & $* * *$ & 0.296 & & 0.351 & & 0.940 & & -0.020 & \\
\hline & -1.51 & & -1.51 & & -1.26 & & -1.26 & & -3.43 & & 0.83 & & 1.04 & & 1.08 & & -0.93 & \\
\hline CEO age & -3.471 & ** & -3.466 & $* *$ & -2.784 & $* *$ & -2.781 & $* *$ & -3.939 & ** & -1.833 & & -0.492 & & 0.300 & & 0.165 & \\
\hline & -2.54 & & -2.54 & & -2.38 & & -2.38 & & -2.57 & & -0.39 & & -0.11 & & 0.04 & & 0.66 & \\
\hline CEO tenure & 0.678 & * & 0.680 & * & 0.813 & ${ }^{* *}$ & 0.815 & $* *$ & -0.990 & ** & 0.380 & & 0.383 & & 2.132 & & 0.038 & \\
\hline & 1.72 & & 1.73 & & 2.30 & & 2.30 & & -2.15 & & 0.27 & & 0.28 & & 0.69 & & 0.49 & \\
\hline Obs. & 8181 & & 8181 & & 8201 & & 8201 & & 7945 & & 3365 & & 3842 & & 785 & & 3365 & \\
\hline $\mathrm{R}^{2}$ & 0.35 & & 0.3545 & & 0.41 & & 0.4112 & & 0.21 & & 0.31 & & 0.31 & & 0.52 & & 0.27 & \\
\hline Adj. $R^{2}$ & 0.34 & & 0.3357 & & 0.39 & & 0.3941 & & 0.19 & & 0.27 & & 0.27 & & 0.41 & & 0.23 & \\
\hline
\end{tabular}


Panel C: Local director labor markets and specialized board expertise

\begin{tabular}{|c|c|c|c|c|c|c|c|c|c|c|c|c|}
\hline \multirow{4}{*}{ Local director pool (R\&D) } & \multicolumn{2}{|c|}{$\begin{array}{c}R \& D \\
\text { Expertise (\%) }\end{array}$} & \multicolumn{2}{|c|}{$\begin{array}{c}R \& D \\
\text { Expertise (\%) }\end{array}$} & \multicolumn{2}{|c|}{$\begin{array}{c}\text { Tech } \\
\text { Expertise (\%) }\end{array}$} & \multicolumn{2}{|c|}{$\begin{array}{c}\text { Tech } \\
\text { Expertise (\%) }\end{array}$} & \multicolumn{2}{|c|}{$\begin{array}{c}\text { Financial } \\
\text { Expertise (\%) }\end{array}$} & \multicolumn{2}{|c|}{$\begin{array}{c}\text { Legal } \\
\text { Expertise (\%) }\end{array}$} \\
\hline & \multicolumn{2}{|l|}{$\mathrm{I}$} & \multicolumn{2}{|l|}{ II } & \multicolumn{2}{|l|}{ III } & \multicolumn{2}{|l|}{ IV } & \multicolumn{2}{|l|}{$\mathrm{V}$} & \multicolumn{2}{|l|}{ VI } \\
\hline & 0.037 & *** & 0.037 & $* * *$ & & & & & & & & \\
\hline & 2.83 & & 3.19 & & & & & & & & & \\
\hline \multirow[t]{2}{*}{ Local director pool (tech) } & & & & & 0.042 & $* * *$ & 0.042 & $* * *$ & & & & \\
\hline & & & & & 4.82 & & 5.16 & & & & & \\
\hline \multirow[t]{2}{*}{ Financial institutions } & & & & & & & & & 0.391 & $*$ & & \\
\hline & & & & & & & & & 1.95 & & & \\
\hline \multirow[t]{2}{*}{ Law firms } & & & & & & & & & & & 0.618 & ** \\
\hline & & & & & & & & & & & 2.21 & \\
\hline \multirow[t]{2}{*}{ Firm size } & 0.016 & & 0.018 & & 0.006 & & 0.002 & & -0.528 & ** & 0.502 & ** \\
\hline & 1.21 & & 1.42 & & 0.51 & & 0.23 & & -2.21 & & 2.20 & \\
\hline \multirow[t]{2}{*}{ Sales growth } & 0.061 & & 0.039 & & 0.048 & & 0.041 & & 0.328 & & 0.585 & \\
\hline & 1.48 & & 1.04 & & 1.38 & & 1.36 & & 0.47 & & 0.98 & \\
\hline \multirow[t]{2}{*}{ Firm age } & -0.028 & & -0.039 & ${ }^{* *}$ & -0.015 & & -0.016 & & -1.347 & $* * *$ & 0.145 & \\
\hline & -1.37 & & -2.08 & & -0.94 & & -1.12 & & -2.99 & & 0.35 & \\
\hline \multirow[t]{2}{*}{ Firm risk } & 0.008 & & 0.001 & & 0.014 & & 0.008 & & 0.445 & ${ }^{* *}$ & 0.086 & \\
\hline & 0.62 & & 0.05 & & 1.21 & & 0.74 & & 2.33 & & 0.52 & \\
\hline \multirow[t]{2}{*}{ Institutional ownership } & 0.001 & & 0.001 & & -0.001 & & -0.001 & & & & & \\
\hline & 1.12 & & 0.58 & & -1.38 & & -1.00 & & & & & \\
\hline \multirow[t]{2}{*}{ G Index } & 0.007 & & 0.007 & & -0.002 & & -0.002 & & & & & \\
\hline & 1.11 & & 1.33 & & -0.49 & & -0.57 & & & & & \\
\hline \multirow[t]{2}{*}{ Tangible asset intensity } & 0.217 & $*$ & 0.257 & ** & -0.185 & ${ }^{* *}$ & -0.119 & & -2.374 & & -2.177 & \\
\hline & 1.87 & & 2.39 & & -2.04 & & -1.42 & & -0.92 & & -0.94 & \\
\hline \multirow[t]{2}{*}{ Regulated firms } & & & & & & & & & 11.008 & $* * *$ & 6.744 & \\
\hline & & & & & & & & & 4.14 & & 1.18 & \\
\hline$R \& D$ intensity & 0.007 & $* *$ & 0.009 & ${ }^{* * *}$ & 0.010 & $* * *$ & 0.007 & $* *$ & -15.628 & ** & -12.215 & $*$ \\
\hline & 2.09 & & 2.86 & & 3.26 & & 2.06 & & -2.22 & & -1.79 & \\
\hline CEO age & -0.005 & & -0.001 & & -0.005 & $* *$ & -0.003 & & -2.060 & ** & 1.047 & \\
\hline & -1.47 & & -0.40 & & -2.11 & & -1.05 & & -2.30 & & 1.21 & \\
\hline CEO tenure & 0.006 & & -0.014 & & -0.053 & & -0.062 & ** & -0.775 & $* * *$ & 0.481 & $*$ \\
\hline & 0.11 & & -0.30 & & -1.37 & & -2.12 & & -2.84 & & 1.75 & \\
\hline CEO ownership & -0.014 & & -0.020 & $*$ & 0.004 & & 0.001 & & -0.006 & & 0.059 & \\
\hline & -1.03 & & -1.66 & & 0.37 & & 0.08 & & -0.11 & & 1.02 & \\
\hline Obs. & 3339 & & 3813 & & 3339 & & 3813 & & 9667 & & 9667 & \\
\hline $\mathrm{R}^{2}$ & 0.28 & & 0.31 & & 0.29 & & 0.28 & & 0.18 & & 0.18 & \\
\hline Adj. $\mathrm{R}^{2}$ & 0.24 & & 0.27 & & 0.25 & & 0.24 & & 0.15 & & 0.16 & \\
\hline
\end{tabular}




\section{Table 6. The effect of board independence on CEO pay and turnover}

We use the 1996-2006 sample of Compustat/CRSP firms that have RiskMetrics corporate governance measures, 13f institutional holdings, and Execucomp data available, excluding firms with total assets below twenty million, regulated financial and utility firms (SIC codes 6000-6999 and 4900-4999), and firms headquartered outside the continental US. For this test, observations in the top quartile of total assets are excluded from the sample. The dependent variables are: incentive/total CEO pay (column I); incentive/total CEO pay (II) (column II); total CEO pay (column III); an indicator for CEO turnover (excluding CEO deaths) in a given year (columns IV-V). Instrumental variables regressions are used. Independent directors (\%) (as well as board size or local independent directors (\%)) is predicted from the local director pool, big and medium-sized city indicators, industry median independent directors $(\%)$ and second-stage controls. Also, turnover-performance sensitivity regressions use industry median stock return and the product of industry medians of stock return and independent directors (\%) to predict a firm's independent directors (\%)*stock return). Stock return is the annual average of a firm's monthly stock returns in excess of the value-weighted CRSP return. Three-digit SIC industry and year fixed effects are included. Robust t-statistics adjusted for clustering by firm are italicized. In all regressions, the null hypothesis of weak instruments is rejected. For purposes of comparison, coefficients of key variables estimated using ordinary least squares using the same model specifications are reported at the bottom of the table. The symbols ${ }^{* * *},{ }^{* *}$ and ${ }^{*}$ denote significance at the $1 \%, 5 \%$ and $10 \%$ levels respectively.

\begin{tabular}{|c|c|c|c|c|c|c|c|c|c|c|}
\hline \multirow{4}{*}{ Independent directors (\%) } & \multicolumn{2}{|c|}{$\begin{array}{c}\text { Incentive/ } \\
\text { Total CEO } \\
\text { pay }\end{array}$} & \multicolumn{2}{|c|}{$\begin{array}{c}\text { Incentive/ } \\
\text { Total CEO } \\
\text { pay (II) }\end{array}$} & \multicolumn{2}{|c|}{$\begin{array}{c}\text { Total } \\
\text { CEO pay }\end{array}$} & \multicolumn{2}{|c|}{$\begin{array}{l}\text { CEO } \\
\text { turnover }\end{array}$} & \multicolumn{2}{|c|}{$\begin{array}{c}\text { CEO } \\
\text { turnover }\end{array}$} \\
\hline & \multicolumn{2}{|l|}{ I } & \multicolumn{2}{|l|}{ II } & \multicolumn{2}{|l|}{ III } & \multicolumn{2}{|l|}{ IV } & \multicolumn{2}{|l|}{$\mathrm{V}$} \\
\hline & 0.324 & **** & 0.286 & ${ }^{* * * *}$ & -0.009 & & 0.002 & ${ }^{* *}$ & 0.002 & *** \\
\hline & 3.02 & & 2.76 & & -0.51 & & 1.97 & & 2.15 & \\
\hline Independent directors $(\%)^{*}$ & & & & & & & & & -0.048 & * \\
\hline Return & & & & & & & & & -1.65 & \\
\hline Firm size & 3.929 & $* * *$ & 5.261 & ${ }^{* * *}$ & -1.960 & ${ }^{* * *}$ & 0.003 & & 0.003 & \\
\hline & 6.36 & & 8.57 & & -13.96 & & 0.62 & & 0.61 & \\
\hline Sales growth & 0.668 & & 2.051 & & 0.905 & ${ }^{* * *}$ & -0.060 & ${ }^{* * *}$ & -0.045 & ${ }^{* * *}$ \\
\hline & 0.47 & & 1.54 & & 2.74 & & -4.37 & & -3.14 & \\
\hline Firm age & -2.492 & $* * *$ & -1.999 & ** & -0.025 & & 0.010 & & 0.010 & \\
\hline & -3.17 & & -2.49 & & -0.15 & & 1.47 & & 1.48 & \\
\hline Firm risk & 1.781 & *** & 1.704 & ${ }^{* * *}$ & 0.349 & ${ }^{* * *}$ & 0.001 & & 0.003 & \\
\hline & 3.88 & & 3.78 & & 3.40 & & 0.32 & & 0.59 & \\
\hline Institutional ownership & 0.195 & $* * *$ & 0.215 & ${ }^{* * *}$ & 0.018 & ${ }^{* *}$ & -0.001 & ${ }^{* * *}$ & -0.001 & ${ }^{* *}$ \\
\hline & 5.33 & & 5.93 & & 2.26 & & -2.59 & & -2.25 & \\
\hline G Index & -0.335 & & -0.126 & & 0.005 & & 0.002 & & 0.002 & \\
\hline & -1.45 & & -0.56 & & 0.12 & & 0.99 & & 0.91 & \\
\hline Tangible asset intensity & -7.549 & * & -6.529 & & -1.188 & & -0.067 & * & -0.075 & ${ }^{* *}$ \\
\hline & -1.88 & & -1.63 & & -1.58 & & -1.82 & & -2.03 & \\
\hline R\&D intensity indicator & 56.622 & $* * *$ & 54.761 & $* * *$ & 13.606 & ${ }^{* * *}$ & -0.015 & & 0.008 & \\
\hline & 5.23 & & 5.69 & & 4.13 & & -0.17 & & 0.08 & \\
\hline CEO ownership & -0.356 & *** & -0.440 & ${ }^{* * *}$ & -0.082 & ${ }^{* * *}$ & & & 0.003 & \\
\hline & -3.54 & & -4.20 & & -4.57 & & & & 0.63 & \\
\hline CEO age & -2.677 & & -4.784 & $* * *$ & -0.539 & $* *$ & & & 0.002 & ${ }^{* *}$ \\
\hline & -1.62 & & -2.97 & & -2.20 & & & & 2.15 & \\
\hline CEO tenure & -1.996 & $* * *$ & -2.932 & $* * *$ & -0.313 & ${ }^{* * *}$ & & & -0.048 & $*$ \\
\hline & -3.86 & & -5.68 & & -3.06 & & & & -1.65 & \\
\hline Industry cluster & & & & & 0.506 & ${ }^{* * *}$ & & & & \\
\hline & & & & & 3.12 & & & & & \\
\hline CEO Chair & & & & & 0.805 & ${ }^{* * *}$ & & & & \\
\hline & & & & & 3.66 & & & & & \\
\hline Dividend yield & & & & & -0.110 & ${ }^{* *}$ & 0.004 & & 0.003 & \\
\hline & & & & & -2.00 & & 0.92 & & 0.61 & \\
\hline Return & & & & & & & & & 2.929 & \\
\hline & & & & & & & & & 1.64 & \\
\hline Past return & & & & & 0.122 & ${ }^{* * *}$ & & & -0.378 & *** \\
\hline & & & & & 5.42 & & & & -3.29 & \\
\hline
\end{tabular}




\begin{tabular}{|c|c|c|c|c|c|c|c|c|c|c|}
\hline Capex & & & & & 0.034 & & & & & \\
\hline & & & & & 1.64 & & & & & \\
\hline High tech & & & & & 0.207 & & & & & \\
\hline & & & & & 0.23 & & & & & \\
\hline Foreign geographic segment & & & & & 0.444 & ** & & & & \\
\hline & & & & & 2.13 & & & & & \\
\hline Business segments & & & & & -0.445 & $* * *$ & & & & \\
\hline & & & & & -3.24 & & & & & \\
\hline High sunshine & & & & & 0.362 & & & & & \\
\hline & & & & & 1.54 & & & & & \\
\hline Industry median & & & & & 0.643 & $* * *$ & & & & \\
\hline & & & & & 8.95 & & & & & \\
\hline Obs. & 6566 & & 6566 & & 5241 & & 6902 & & 6900 & \\
\hline First-stage Cragg-Donald stat. & 81.15 & & 81.15 & & 65.22 & & 104.88 & & 41.18 & \\
\hline $\begin{array}{l}\text { Hausman test (endogeneity of } \\
\text { independent directors }(\%) \text { ) }\end{array}$ & 4.340 & ** & 3.108 & * & 0.879 & & 4.320 & ${ }^{* *}$ & 4.434 & ** \\
\hline & 0.055 & ${ }^{*}$ & 0.079 & ${ }^{* * * *}$ & 0.005 & & $-2 . \mathrm{E}-04$ & & $-2 . E-04$ & \\
\hline OLS: Independent directors (\%) & 1.94 & & 2.84 & & 0.82 & & -0.69 & & -0.93 & \\
\hline OLS: Independent directors (\%)* & & & & & & & & & 0.008 & \\
\hline Return & & & & & & & & & 1.57 & \\
\hline
\end{tabular}




\section{Table 7. The effect of board independence on firm profitability and operating performance}

We use the 1996-2006 sample of Compustat/CRSP firms that have RiskMetrics corporate governance measures, 13f institutional holdings, and Execucomp data available, excluding firms with total assets below twenty million, regulated financial and utility firms (SIC codes 6000-6999 and 4900-4999), and firms headquartered outside the continental US. For this test, observations in the top quartile of total assets are excluded from the sample. Variable definitions are presented in Appendix A. The dependent variables are ROA (columns I-II) and operating cash flow (columns III-IV). Instrumental variables regressions are used. Independent directors (\%) is predicted from the local director pool, big and medium-sized city indicators, industry median independent directors (\%) and second-stage controls. Three-digit SIC industry and year fixed effects are included. Robust t-statistics adjusted for clustering by firm are italicized. In all regressions, the null hypothesis of weak instruments is rejected. For purposes of comparison, coefficients of key variables estimated using ordinary least squares are reported at the bottom of the table. The symbols ${ }^{* * *},{ }^{* *}$ and ${ }^{*}$ denote significance at the $1 \%, 5 \%$ and $10 \%$ levels respectively.

\begin{tabular}{|c|c|c|c|c|c|c|c|c|}
\hline \multirow{4}{*}{ Independent directors (\%) } & \multicolumn{2}{|l|}{ ROA } & \multicolumn{2}{|l|}{ ROA } & \multicolumn{2}{|l|}{$\mathrm{OCF}$} & \multicolumn{2}{|c|}{$\mathrm{OCF}$} \\
\hline & \multicolumn{2}{|l|}{$\mathrm{I}$} & \multicolumn{2}{|l|}{ II } & \multicolumn{2}{|l|}{ III } & \multicolumn{2}{|l|}{ IV } \\
\hline & 0.097 & *** & 0.067 & ${ }^{* *}$ & 0.104 & $* * *$ & 0.080 & $* *$ \\
\hline & 2.96 & & 2.23 & & 3.03 & & 2.43 & \\
\hline \multirow[t]{2}{*}{ Firm size } & 1.466 & & 0.453 & & 0.983 & & 0.196 & \\
\hline & 3.48 & & 1.20 & & 2.53 & & 0.55 & \\
\hline \multirow[t]{2}{*}{ Sales growth } & 4.232 & ${ }^{* * *}$ & 4.342 & *** & 2.327 & & 2.359 & \\
\hline & 2.66 & & 2.90 & & 1.31 & & 1.38 & \\
\hline \multirow[t]{2}{*}{ Firm age } & -0.349 & & -1.067 & *** & -0.725 & ** & -1.206 & *** \\
\hline & -0.98 & & -3.39 & & -2.03 & & -3.60 & \\
\hline \multirow[t]{2}{*}{ Institutional ownership } & 0.118 & ${ }^{* * *}$ & 0.090 & *** & 0.091 & $* * *$ & 0.072 & $* * *$ \\
\hline & 6.12 & & 5.12 & & 4.73 & & 3.99 & \\
\hline \multirow[t]{2}{*}{ Tangible asset intensity } & 8.374 & ${ }^{* * *}$ & 6.854 & $* * *$ & 8.825 & $* * *$ & 7.536 & $* * *$ \\
\hline & 3.86 & & 3.44 & & 4.40 & & 4.01 & \\
\hline \multirow[t]{2}{*}{ Industry cluster } & -1.112 & ${ }^{* * *}$ & -0.557 & $*$ & -0.428 & & -0.017 & \\
\hline & -3.14 & & -1.71 & & -1.21 & & -0.05 & \\
\hline \multirow[t]{2}{*}{ G Index (state laws) } & 0.094 & & & & 0.061 & & & \\
\hline & 0.44 & & & & 0.30 & & & \\
\hline \multirow[t]{2}{*}{ G Index } & & & -0.080 & & & & -0.149 & \\
\hline & & & -0.85 & & & & -1.60 & \\
\hline \multirow[t]{2}{*}{ Firm risk } & & & -3.574 & $* * *$ & & & -2.918 & *** \\
\hline & & & -14.98 & & & & -13.33 & \\
\hline \multirow[t]{2}{*}{ R\&D intensity indicator } & & & -0.119 & & & & 0.454 & \\
\hline & & & -0.19 & & & & 0.71 & \\
\hline \multirow[t]{2}{*}{ CEO age } & & & 0.417 & & & & 0.028 & \\
\hline & & & 0.79 & & & & 0.05 & \\
\hline \multirow[t]{2}{*}{ CEO ownership } & & & 0.046 & & & & 0.083 & $* *$ \\
\hline & & & 1.20 & & & & 2.21 & \\
\hline \multirow[t]{2}{*}{ CEO tenure } & & & 0.444 & $* *$ & & & 0.301 & \\
\hline & & & 2.17 & & & & 1.42 & \\
\hline Obs. & 7271 & & 7271 & & 7271 & & 7271 & \\
\hline First-stage Cragg-Donald statistic & 112.57 & & 105.31 & & 112.57 & & 105.31 & \\
\hline $\begin{array}{l}\text { Hausman test (endogeneity of } \\
\text { independent directors }(\%) \text { ) }\end{array}$ & 9.25 & ${ }^{* * *}$ & 3.68 & $*$ & 11.42 & $* * *$ & 5.88 & ** \\
\hline \multirow{2}{*}{ OLS: Independent directors (\%) } & -0.034 & ** & -0.022 & & -0.020 & & -0.010 & \\
\hline & -2.29 & & -1.62 & & -1.47 & & -0.72 & \\
\hline
\end{tabular}




\section{Table 8. The effect of board independence on firm value}

We use the 1996-2006 sample of Compustat/CRSP firms that have RiskMetrics corporate governance measures, 13f institutional holdings, and Execucomp data available, excluding firms with total assets below twenty million, regulated financial and utility firms (SIC codes 60006999 and 4900-4999), and firms headquartered outside the continental US. For this test, observations in the top quartile of total assets are excluded from the sample. Variable definitions are presented in Appendix A. The dependent variable is market-to-book ratio. Instrumental variables regressions are used. Independent directors (\%) is predicted from the local director pool, big and medium-sized city indicators, industry median independent directors (\%) and second-stage controls). Three-digit SIC industry and year fixed effects are included. Robust tstatistics adjusted for clustering by firm are italicized. In all regressions, the null hypothesis of weak instruments is rejected. For purposes of comparison, coefficients of key variables estimated using ordinary least squares using the same model specifications are reported at the bottom of the table. The symbols ${ }^{* * *},{ }^{* *}$ and ${ }^{*}$ denote significance at the $1 \%, 5 \%$ and $10 \%$ levels respectively.

\begin{tabular}{|c|c|c|c|c|c|c|}
\hline \multirow{4}{*}{ Independent directors (\%) } & \multicolumn{2}{|l|}{$\mathrm{M} / \mathrm{B}$} & \multicolumn{2}{|l|}{$\mathrm{M} / \mathrm{B}$} & \multicolumn{2}{|l|}{$\mathrm{M} / \mathrm{B}$} \\
\hline & \multicolumn{2}{|l|}{ I } & \multicolumn{2}{|l|}{ II } & \multicolumn{2}{|l|}{ III } \\
\hline & 0.010 & $* *$ & 0.009 & ** & 0.009 & $* *$ \\
\hline & 2.56 & & 2.37 & & 2.26 & \\
\hline \multirow[t]{2}{*}{ Firm size } & -0.080 & & -0.095 & & -0.095 & \\
\hline & -2.04 & & -2.36 & & -2.36 & \\
\hline \multirow[t]{2}{*}{ Sales growth } & 1.104 & $* * *$ & 1.086 & $* * *$ & 1.069 & $* * *$ \\
\hline & 8.93 & & 9.01 & & 8.89 & \\
\hline \multirow[t]{2}{*}{ Firm age } & -0.119 & $* *$ & -0.109 & $* *$ & -0.095 & $* *$ \\
\hline & -2.53 & & -2.38 & & -2.03 & \\
\hline \multirow[t]{2}{*}{ Institutional ownership } & 0.007 & $* * *$ & 0.007 & $* * *$ & 0.007 & *** \\
\hline & 3.57 & & 3.72 & & 3.56 & \\
\hline \multirow[t]{2}{*}{ Tangible asset intensity } & -0.349 & & -0.388 & $*$ & -0.387 & $*$ \\
\hline & -1.53 & & -1.71 & & -1.70 & \\
\hline \multirow[t]{2}{*}{ Industry cluster } & 0.240 & $* * *$ & 0.236 & $* * *$ & 0.235 & $* * *$ \\
\hline & 4.58 & & 4.39 & & 4.37 & \\
\hline \multirow[t]{2}{*}{ G Index (state laws) } & 0.002 & & & & & \\
\hline & 0.08 & & & & & \\
\hline \multirow[t]{2}{*}{ G Index } & & & -0.027 & * & -0.027 & * \\
\hline & & & -1.89 & & -1.91 & \\
\hline \multirow[t]{2}{*}{ Firm risk } & & & -0.094 & $* * *$ & -0.102 & $* * *$ \\
\hline & & & -3.88 & & -4.21 & \\
\hline \multirow[t]{2}{*}{ R\&D intensity indicator } & & & 0.231 & $* *$ & 0.227 & $* *$ \\
\hline & & & 2.55 & & 2.50 & \\
\hline \multirow[t]{2}{*}{ CEO age } & & & -0.104 & & -0.104 & \\
\hline & & & -1.39 & & -1.40 & \\
\hline \multirow[t]{2}{*}{ CEO ownership } & & & 0.006 & & 0.006 & \\
\hline & & & 1.11 & & 1.07 & \\
\hline \multirow[t]{2}{*}{ CEO tenure } & & & 0.047 & & 0.048 & \\
\hline & & & 1.62 & & 1.63 & \\
\hline \multirow[t]{2}{*}{ Dividend yield } & & & & & -0.040 & $* *$ \\
\hline & & & & & -2.22 & \\
\hline \multirow[t]{2}{*}{ Dual class firm } & & & & & -0.104 & \\
\hline & & & & & -0.91 & \\
\hline Obs. & 7271 & & 7271 & & 7271 & \\
\hline First-stage Cragg-Donald statistic & 112.57 & & 105.31 & & 104.65 & \\
\hline $\begin{array}{l}\text { Hausman test (endogeneity of } \\
\text { independent directors }(\%) \text { ) }\end{array}$ & 4.56 & $* *$ & 3.36 & $*$ & 3.26 & $*$ \\
\hline \multirow{2}{*}{ OLS: Independent directors (\%) } & 0.001 & & 0.001 & & 0.001 & \\
\hline & 0.52 & & 0.69 & & 0.59 & \\
\hline
\end{tabular}


Table 9. Additional tests: the effects of board independence, board size and local directors on firm value and performance

We use the 1996-2006 sample of Compustat/CRSP firms that have RiskMetrics corporate governance measures, 13f institutional holdings, and Execucomp data available, excluding firms with total assets below twenty million, regulated financial and utility firms (SIC codes 60006999 and 4900-4999), and firms headquartered outside the continental US. For this test, observations in the top quartile of total assets are excluded from the sample. Variable definitions are presented in Appendix A. The dependent variables are market-to-book (columns I-II), ROA (columns III-IV), and operating cash flow (columns V-VI). Instrumental variables regressions are used. Independent directors (\%) (as well as board size or local independent directors (\%)) is predicted from the local director pool, big and medium-sized city indicators, industry median independent directors (\%) and second-stage controls (as well as industry median board size or local independent directors (\%) for the latter two dependent variables respectively). Three-digit SIC industry and year fixed effects are included. Robust t-statistics adjusted for clustering by firm are italicized. The symbols ${ }^{* * *},{ }^{* *}$ and ${ }^{*}$ denote significance at the $1 \%, 5 \%$ and $10 \%$ levels respectively.

\begin{tabular}{|c|c|c|c|c|c|c|c|c|c|c|c|c|}
\hline & $\mathrm{M} / \mathrm{B}$ & & $\mathrm{M} / \mathrm{B}$ & & ROA & & ROA & & $\mathrm{OCF}$ & & $\mathrm{OCF}$ & \\
\hline \multirow{3}{*}{ Independent directors (\%) } & $\mathrm{I}$ & & II & & III & & IV & & $\mathrm{V}$ & & VI & \\
\hline & 0.009 & ** & 0.015 & ${ }^{*}$ & 0.066 & ** & 0.148 & ** & 0.079 & ** & 0.250 & $* * *$ \\
\hline & 2.33 & & 1.92 & & 2.19 & & 2.34 & & 2.41 & & 3.57 & \\
\hline \multirow{2}{*}{ Firm size } & -0.096 & & -0.019 & & 0.556 & & 0.702 & & 0.330 & & 0.235 & \\
\hline & -1.90 & & -0.27 & & 1.28 & & 0.99 & & 0.77 & & 0.38 & \\
\hline \multirow[t]{2}{*}{ Sales growth } & 1.074 & *** & 1.275 & $* * *$ & 4.305 & ${ }^{* * *}$ & 4.850 & ** & 2.312 & & 6.154 & *** \\
\hline & 8.89 & & 4.74 & & 2.87 & & 2.04 & & 1.35 & & 2.63 & \\
\hline \multirow[t]{2}{*}{ Firm age } & -0.093 & * & -0.093 & & -0.997 & ${ }^{* * *}$ & -0.975 & $* *$ & -1.117 & *** & -0.706 & \\
\hline & -1.86 & & -1.13 & & -2.97 & & -2.17 & & -3.10 & & -1.40 & \\
\hline \multirow[t]{2}{*}{ Firm risk } & -0.101 & *** & -0.037 & & -3.606 & ${ }^{* * *}$ & -3.188 & $* * *$ & -2.959 & $* * *$ & -2.647 & $* * *$ \\
\hline & -4.00 & & -0.87 & & -14.62 & & -9.01 & & -13.01 & & -7.27 & \\
\hline \multirow[t]{2}{*}{ Institutional ownership } & 0.007 & $* * *$ & 0.007 & ** & 0.087 & $* * *$ & 0.073 & ${ }^{* * *}$ & 0.069 & ${ }^{* * *}$ & 0.051 & * \\
\hline & 3.34 & & 2.02 & & 4.91 & & 2.63 & & 3.70 & & 1.88 & \\
\hline \multirow[t]{2}{*}{ G Index } & -0.026 & * & -0.034 & & -0.069 & & -0.114 & & -0.135 & & -0.212 & \\
\hline & -1.77 & & -1.25 & & -0.72 & & -0.73 & & -1.43 & & -1.22 & \\
\hline \multirow[t]{2}{*}{ Tangible asset intensity } & -0.385 & * & -0.729 & * & 6.937 & ${ }^{* * *}$ & 5.910 & $*$ & 7.641 & $* * *$ & 5.069 & \\
\hline & -1.67 & & -1.79 & & 3.47 & & 1.72 & & 4.05 & & 1.47 & \\
\hline \multirow[t]{2}{*}{$\mathrm{R} \& \mathrm{D}$ intensity indicator } & 0.223 & ** & 0.224 & * & -0.084 & & 1.225 & & 0.497 & & 0.982 & \\
\hline & 2.46 & & 1.70 & & -0.13 & & 1.25 & & 0.77 & & 0.86 & \\
\hline \multirow[t]{2}{*}{ CEO age } & -0.105 & & -0.128 & & 0.452 & & -0.994 & & 0.077 & & -1.022 & \\
\hline & -1.38 & & -1.20 & & 0.85 & & -1.23 & & 0.15 & & -1.09 & \\
\hline \multirow[t]{2}{*}{ CEO ownership } & 0.006 & & 0.026 & $* *$ & 0.040 & & -0.013 & & 0.076 & ** & 0.112 & \\
\hline & 1.04 & & 2.42 & & 1.04 & & -0.17 & & 1.99 & & 1.07 & \\
\hline \multirow[t]{2}{*}{ CEO tenure } & 0.045 & & -0.026 & & 0.427 & ${ }^{* *}$ & 0.991 & $* * *$ & 0.280 & & 0.708 & $*$ \\
\hline & 1.55 & & -0.52 & & 2.07 & & 2.79 & & 1.31 & & 1.79 & \\
\hline \multirow[t]{2}{*}{ Industry cluster } & 0.236 & $* * *$ & 0.213 & ** & -0.588 & * & -0.488 & & -0.059 & & 0.205 & \\
\hline & 4.34 & & 2.48 & & -1.78 & & -0.91 & & -0.17 & & 0.37 & \\
\hline \multirow[t]{2}{*}{ Dividend yield } & -0.041 & ** & -0.035 & & & & & & & & & \\
\hline & -2.19 & & -1.26 & & & & & & & & & \\
\hline \multirow[t]{2}{*}{ Board size } & -0.004 & & & & -1.318 & & & & -1.703 & & & \\
\hline & -0.01 & & & & -0.60 & & & & -0.70 & & & \\
\hline \multirow[t]{2}{*}{ Local independent directors $(\%)$} & & & 0.000 & & & & -0.005 & & & & -0.003 & \\
\hline & & & 0.14 & & & & -0.41 & & & & -0.21 & \\
\hline Obs. & 7271 & & 1975 & & 7271 & & 1975 & & 7271 & & 1975 & \\
\hline First-stage Cragg-Donald statistic & 71.95 & & 17.68 & & 72.55 & & 17.69 & & 72.55 & & 17.69 & \\
\hline $\begin{array}{l}\text { Hausman test (endogeneity of } \\
\text { independent directors }(\%) \text { ) }\end{array}$ & 3.15 & * & 3.81 & * & 3.54 & * & 4.85 & $* *$ & 5.68 & ** & 11.25 & *** \\
\hline \multirow[t]{2}{*}{ OLS: Independent directors (\%) } & 0.001 & & -0.001 & & -0.022 & & -0.007 & & -0.010 & & -0.004 & \\
\hline & 0.73 & & -0.19 & & -1.62 & & -0.33 & & -0.73 & & -0.16 & \\
\hline \multirow[t]{2}{*}{ Board size } & -0.097 & & & & -0.003 & & & & -0.890 & & & \\
\hline & -0.77 & & & & 0.00 & & & & -0.93 & & & \\
\hline \multirow[t]{2}{*}{ Local independent directors (\%) } & & & 2.E-04 & & & & 0.011 & & & & 0.011 & \\
\hline & & & 0.18 & & & & 1.56 & & & & 1.42 & \\
\hline
\end{tabular}




\section{Appendix A. Variable definitions.}

This table presents first stage estimates of instrumental variables regressions from Table 8. We use the 1996-2006 sample of Compustat/CRSP firms that have RiskMetrics corporate governance measures, 13f institutional holdings, and Execucomp data available, excluding firms with total assets below twenty million, regulated financial and utility firms (SIC codes 6000-6999 and 4900-4999), and firms headquartered outside the continental US. Tests of legal, financial and executive (where indicated) expertise use BoardEx data on outside directors for the 2002-2008 period, excluding firms with missing CRSP/Compustat or Execucomp data, firms with total assets below twenty million, firms headquartered outside continental US, and boards reporting fewer than three directors but including financials and regulated utilities.

\begin{tabular}{|c|c|}
\hline Variable & Definition \\
\hline \multicolumn{2}{|l|}{ Board characteristics } \\
\hline Independent directors (\%) & Percent of independent directors on the board. RiskMetrics. \\
\hline Gray directors (\%) & $\begin{array}{l}\text { Percent of gray directors on the board. Gray directors are professional service providers, customers, suppliers, former employees, directors designated under an } \\
\text { agreement with a group or by a significant shareholder, majority holders, relatives of executives, recipients of gifts, certain interlocking directors (a director and } \\
\text { executive of our firm sits on another board that has an executive and director who also sit on our board), and others, as identified in proxies and disclosures. RiskMetrics. }\end{array}$ \\
\hline Inside directors (\%) & Percent of inside directors on the board. RiskMetrics. \\
\hline Board size & Log of the number of directors on the board. RiskMetrics. \\
\hline $\begin{array}{l}\text { Local independent } \\
\text { directors (\%) }\end{array}$ & $\begin{array}{l}\text { rcent of local independent directors (employed within sixty miles of the firm) among independent directors with corporate positions (officer of another firm, as } \\
\text { ported in RiskMetrics, where location is known). Local Gray Directors (\%) and Local Outside Directors (\%) are defined similarly. }\end{array}$ \\
\hline $\begin{array}{l}\text { Independent dir. distance } \\
\text { to executive job (mean) }\end{array}$ & $\begin{array}{l}\text { Log of one plus average distance in miles to the main executive job held by an independent director on the firm's board, based on independent directors holding } \\
\text { executive jobs. Outside Dir. Distance to Exec. Job (Mean) is defined similarly, except both independent and gray directors are considered. }\end{array}$ \\
\hline $\begin{array}{l}\text { Executives with local } \\
\text { directorships (\%) }\end{array}$ & $\begin{array}{l}\text { Percent of insiders with seats on other local boards (within sixty miles of the firm), as reported in RiskMetrics; defined for firms with at least one insider. Local } \\
\text { Directorships per Insider is average number of seats on other local boards held by the firm's insiders, defined for firms with at least one insider. RiskMetrics. }\end{array}$ \\
\hline Executive expertise (\%) & $\begin{array}{l}\text { Percent of independent (outside, as specified) directors with executive expertise on the board. Executive expertise is defined as holding the title of CEO, CFO, CIO, } \\
\text { COO, president, VP, executive VP, senior VP, partner, managing director, treasurer title, or having insider status on another board. RiskMetrics/BoardEx. }\end{array}$ \\
\hline $\begin{array}{l}\text { Legal expertise (\%) and } \\
\text { Financial expertise (\%) }\end{array}$ & $\begin{array}{l}\text { Percent of directors with specialized expertise on the board. Legal Expertise is defined as having an attorney, counsel, or similar law-related title or holding a law degree. } \\
\text { Financial Expertise is defined as holding the CFO, treasurer, banking, finance, investment or accounting position. Data on outside director expertise for the present and } \\
\text { past years reported in BoardEx is used. }\end{array}$ \\
\hline $\begin{array}{l}R \& D \text { experience }(\%) \text { and } \\
\text { Tech experience }(\%)\end{array}$ & $\begin{array}{l}\text { Percent of outside directors with corporate experience at firms with positive R\&D and high-tech firms (SIC codes } 2833-2836,3570-3577,3600-3674,7371-7379 \text { or } \\
8731-8734 \text {, following Baginski et al. (2004)), respectively, among outside directors with identifiable corporate jobs (officer on another board, where RiskMetrics } \\
\text { identifies the firm). }\end{array}$ \\
\hline \multicolumn{2}{|l|}{ Local director labor markets } \\
\hline Local director pool & $\begin{array}{l}\text { Log of one plus the number of US nonfinancial firms headquartered within sixty miles of the firm's headquarters, excluding firms in the same four-digit SIC (SIC4) } \\
\text { industry. Alternative local pool definitions differ based on (i) geography - hundred-mile radius [Local director pool (100 mi)], the firm's county [Local director pool } \\
\text { (county)], US and Canadian firms in the sixty-mile radius [Local director pool (incl. Canada)]; (ii) firm size - firms in the same or higher quartile of assets [Local } \\
\text { director pool (similar or larger size)] or firms with total assets of at least one hundred million [Local director pool (excl. small)]; and (iii) sample composition - financial } \\
\text { firms and nonfinancial firms, including the firm's industry [Local director pool (all firms)]. }\end{array}$ \\
\hline Law firms & Log of one plus the number of law firms (250 largest law firms in the 2008 Internet Legal Research Group ranking) within a sixty-mile radius of the firm's headquarters. \\
\hline Financial ir & Log of one plus the number of financial institutions (SIC codes 6000-6999) headquartered within sixty miles of the firm. \\
\hline Local director pool (R\&D) & Log of one plus the number of US nonfinancial firms with positive R\&D headquartered within sixty miles of the firm, excluding firms in the same SIC 4 industry. \\
\hline Local director pool (tech) & $\begin{array}{l}\text { one plus the number of US high-tech firms (identified by SIC codes } 2833-2836,3570-3577,3600-3674,7371-7379 \text { or } 8731-8734 \text {, following Baginski et al. } \\
\text { neadquartered within sixty miles of the sample firm, excluding firms in the same SIC4 industry. }\end{array}$ \\
\hline
\end{tabular}

Control variables

Firm size

Sales growth

Log of total assets. Compustat.

$R O A$

Annual change in net sales divided by the previous year's net sales. Compustat.

Ratio of operating income before depreciation to total assets. ROA (\%) is ROA expressed as a percent of total assets. Compustat. 
Log of one plus the number of years since the first listing of the firm's shares in CRSP. CRSP monthly.

Firm visibility Standard deviation of daily excess returns expressed in percent in a given year. CRSP daily.

Institutional ownership

Linear combination of Firm size (0.60), Firm age (0.65), and Number of blockholders (0.46) based on the principal components analysis of these three variables.

Total percentage institutional ownership. Institutional block equals 1 if the firm has a 5\% institutional blockholder. Thomson Reuters.

The Gompers et al. (2003) index of 24 takeover defenses. Similar to existing work, gap years are filled in with adjoining years. RiskMetrics.

CEO age Equals 1 for CEO aged sixty-five and over; 0 otherwise. Execucomp

CEO ownership

Percent ownership stake of the CEO in the firm. Execucomp.

CEO tenure

Log of CEO tenure. Execucomp.

$R \& D$ intensity

Ratio of research and development expenditure to assets; 0 if missing. $R \& D$ intensity indicator equals 1 if $R \& D$ Intensity is positive and 0 otherwise. Compustat.

Tangible asset intensity Ratio of property, plants, and equipment to total assets. Compustat.

Robustness control variables and other location related characteristics

Classified board Indicator variable equal to 1 if the firm has a classified board provision and 0 otherwise. RiskMetrics.

Business segments $\quad$ Log of the number of business segments. Compustat Segments.

Foreign seg

Indicator variable equal to 1 if the firm has a foreign geographic segment and 0 otherwise. Compustat Segments.

NYSE listing

Big and medium-sized city

indicators

Industry cluster

Population density

Upper-income density

Retirement income density

College graduates (\%)

Unemployment (\%)

Indicator variable equal to 1 if the firm's shares are listed on NYSE.

Big city indicator equals 1 if the firm is headquartered in one a top 10 metropolitan statistical area based on the 2000 Census and 0 otherwise. Medium-sized city indicator equals 1 if the firm is headquartered in one of top 11-50 metropolitan statistical areas by population size and 0 otherwise. Compustat; Census (2000).

Log of number of US nonfinancial firms in the same four-digit SIC industry as the sample firm headquartered within sixty miles of the sample firm.

Log of population density in the counties located within sixty miles of the sample firm's headquarters. US Census (2000).

Log of the density of households with income above $\$ 100,000$ in the counties located within sixty miles of the sample firm's headquarters. US Census (2000).

Log of the density of households with retirement income in the counties located within sixty miles of the sample firm's headquarters. US Census (2000).

Percent of college graduates and advanced degree holders in population ages $25+$ within sixty miles of the sample firm's headquarters. US Census (2000) Additional variables used in firm value and compensation regressions

\begin{tabular}{ll}
\hline Market-to-book ratio & Ratio of market value (book value of assets minus book value of equity plus year-end price times common shares outstanding) to book value of assets. Compustat. \\
Incentive/Total CEO pay & Percent of value of CEO option grants in total CEO compensation. Incentive/Total CEO pay (II) uses the sum of option and restricted stock grants. Execucomp. \\
Total CEO pay & Total CEO compensation (including value of option grants), in million, divided by total assets. Execucomp, Compustat \\
CEO turnover & Indicator variable equal to 1 if a change in the CEO has occurred compared to the previous year, according to Execucomp. CEO deaths and retirements are excluded. \\
Dividend yield & Cash dividends per share divided by price at year-end, times hundred. Compustat. \\
Return & Annual average of monthly excess stock return, lagged where specified. CRSP monthly. \\
Dual class firm & Indicator that equals 1 if the firm has dual classes of shares. RiskMetrics. \\
\hline
\end{tabular}




\section{Appendix B. First stage estimates}

This table presents first stage estimates of instrumental variables regressions (the specific estimates are from Table 7). We use the 1996-2006 sample of Compustat/CRSP firms that have RiskMetrics corporate governance measures, 13f institutional holdings, and Execucomp data available, excluding firms with total assets below twenty million, regulated financial and utility firms (SIC codes 6000-6999 and 4900-4999), and firms headquartered outside the continental US. For this test, observations in the top quartile of total assets are excluded from the sample. Variable definitions are presented in Appendix A. Independent directors (\%)is predicted from the local director pool, big and medium-sized city indicators, industry median independent directors (\%) and second-stage controls. Three-digit SIC industry and year fixed effects are included. Robust t-statistics adjusted for clustering by firm are italicized. The symbols $^{* * *},{ }^{* *}$ and ${ }^{*}$ denote significance at the $1 \%, 5 \%$ and $10 \%$ levels respectively.

\begin{tabular}{|c|c|c|c|c|}
\hline \multirow{4}{*}{ Local director pool } & \multicolumn{2}{|c|}{$\begin{array}{l}\text { Independent } \\
\text { directors }(\%)\end{array}$} & \multicolumn{2}{|c|}{$\begin{array}{l}\text { Independent } \\
\text { directors }(\%)\end{array}$} \\
\hline & \multicolumn{2}{|l|}{ I } & \multicolumn{2}{|l|}{ II } \\
\hline & 1.004 & ** & 0.982 & *** \\
\hline & 2.50 & & 2.57 & \\
\hline \multirow[t]{2}{*}{ Big city } & -3.693 & & -2.841 & \\
\hline & -2.18 & & -1.77 & \\
\hline \multirow[t]{2}{*}{ Medium-sized city } & 0.029 & & 0.015 & \\
\hline & 0.02 & & 0.01 & \\
\hline \multirow[t]{2}{*}{ Independent directors (\%) (industry median) } & 0.621 & *** & 0.595 & *** \\
\hline & 17.98 & & 17.21 & \\
\hline \multirow[t]{2}{*}{ Firm size } & -0.072 & & -0.267 & \\
\hline & -0.16 & & -0.59 & \\
\hline \multirow[t]{2}{*}{ Sales growth } & -2.584 & *** & -1.894 & ** \\
\hline & -2.65 & & -2.09 & \\
\hline \multirow[t]{2}{*}{ Firm age } & 1.694 & *** & 1.135 & ** \\
\hline & 2.80 & & 1.97 & \\
\hline \multirow[t]{2}{*}{ Institutional ownership } & 0.209 & *** & 0.169 & *** \\
\hline & 8.89 & & 7.39 & \\
\hline \multirow[t]{2}{*}{ Tangible asset intensity } & 1.434 & & 3.397 & \\
\hline & 0.44 & & 1.09 & \\
\hline \multirow[t]{2}{*}{ Industry cluster } & 0.739 & & 0.596 & \\
\hline & 1.07 & & 0.89 & \\
\hline \multirow[t]{2}{*}{ G Index (state laws) } & -0.035 & & & \\
\hline & -0.10 & & & \\
\hline \multirow[t]{2}{*}{ G Index } & & & 0.690 & *** \\
\hline & & & 4.27 & \\
\hline \multirow[t]{2}{*}{ Firm risk } & & & 0.591 & * \\
\hline & & & 1.90 & \\
\hline \multirow[t]{2}{*}{ R\&D intensity indicator } & & & 3.377 & *** \\
\hline & & & 2.65 & \\
\hline \multirow[t]{2}{*}{ CEO age } & & & -4.449 & *** \\
\hline & & & -5.21 & \\
\hline \multirow[t]{2}{*}{ CEO ownership } & & & -0.303 & *** \\
\hline & & & -4.38 & \\
\hline \multirow[t]{2}{*}{ CEO tenure } & & & -0.355 & \\
\hline & & & -1.03 & \\
\hline Obs. & 7271 & & 7271 & \\
\hline First-stage F-statistic & 86.08 & & 78.55 & \\
\hline
\end{tabular}




\section{Appendix C. Determinants of a firm's propensity to supply local directors}

This table examines firm size and other characteristics in relation to firms' propensity to supply local directors and the service of executives on other local firms' boards. We use the 1996-2006 sample of Compustat/CRSP firms that have RiskMetrics corporate governance measures, 13f institutional holdings, and Execucomp data available, excluding firms with total assets below twenty million, regulated financial and utility firms (SIC codes 6000-6999 and 4900-4999), and firms headquartered outside the continental US. Variable definitions are presented in Appendix A. Ordinary least squares regressions with three-digit SIC industry and year fixed effects. Robust t-statistics adjusted for clustering by firm are italicized. The symbols ${ }^{* * *},{ }^{* *}$ and ${ }^{*}$ denote significance at the $1 \%, 5 \%$ and $10 \%$ levels respectively.

\begin{tabular}{|c|c|c|c|c|c|c|}
\hline \multirow{3}{*}{ Local director pool } & \multirow{2}{*}{\multicolumn{2}{|c|}{$\begin{array}{c}\begin{array}{c}\text { Executives } \\
\text { with Local } \\
\text { Directorships (\%) }\end{array} \\
\text { I }\end{array}$}} & \multirow{2}{*}{\multicolumn{2}{|c|}{$\begin{array}{c}\text { D(Executives } \\
\text { with Local } \\
\text { Directorships }>0 \text { ) }\end{array}$}} & \multirow{2}{*}{\multicolumn{2}{|c|}{$\begin{array}{c}\text { Local } \\
\text { Directorships } \\
\text { per Executive } \\
\text { III }\end{array}$}} \\
\hline & & & & & & \\
\hline & 2.107 & **** & 0.025 & *** & 0.030 & *** \\
\hline & 5.27 & & 4.71 & & 5.23 & \\
\hline \multirow[t]{2}{*}{ Firm size } & 3.676 & $* * *$ & 0.054 & *** & 0.043 & *** \\
\hline & 6.17 & & 7.30 & & 5.09 & \\
\hline \multirow[t]{2}{*}{ Sales growth } & -4.531 & *** & -0.039 & *** & -0.058 & *** \\
\hline & -4.47 & & -2.79 & & -4.32 & \\
\hline \multirow[t]{2}{*}{ ROA } & 7.719 & & 0.092 & & 0.118 & $*$ \\
\hline & 1.49 & & 1.33 & & 1.71 & \\
\hline \multirow[t]{2}{*}{ Firm age } & 2.441 & *** & 0.029 & ** & 0.033 & *** \\
\hline & 2.67 & & 2.42 & & 2.82 & \\
\hline \multirow[t]{2}{*}{ Firm risk } & -0.398 & & -0.013 & $*$ & -0.010 & \\
\hline & -0.81 & & -1.81 & & -1.52 & \\
\hline \multirow[t]{2}{*}{ Institutional ownership } & -0.035 & & -0.001 & & -0.001 & \\
\hline & -0.92 & & -1.29 & & -0.98 & \\
\hline \multirow[t]{2}{*}{ G Index } & 0.588 & $* *$ & 0.010 & *** & 0.008 & $* *$ \\
\hline & 2.32 & & 2.78 & & 2.29 & \\
\hline \multirow[t]{2}{*}{ Tangible asset intensity } & -7.928 & $*$ & -0.120 & * & -0.101 & \\
\hline & -1.66 & & -1.81 & & -1.63 & \\
\hline \multirow[t]{2}{*}{$R \& D$ intensity indicator } & 0.574 & & -0.009 & & 0.013 & \\
\hline & 0.30 & & -0.34 & & 0.52 & \\
\hline \multirow[t]{2}{*}{ CEO ownership } & -0.088 & & -0.001 & & -0.002 & * \\
\hline & -0.97 & & -0.88 & & -1.66 & \\
\hline \multirow[t]{2}{*}{ CEO age } & -1.619 & & -0.024 & & -0.022 & \\
\hline & -0.92 & & -1.06 & & -1.03 & \\
\hline \multirow[t]{2}{*}{ CEO tenure } & 1.522 & $* *$ & 0.022 & *** & 0.024 & $* * *$ \\
\hline & 2.55 & & 2.67 & & 2.74 & \\
\hline Obs. & 9628 & & 9628 & & 9628 & \\
\hline $\mathrm{R}^{2}$ & 0.17 & & 0.18 & & 0.17 & \\
\hline Adj. $R^{2}$ & 0.15 & & 0.16 & & 0.15 & \\
\hline
\end{tabular}

